\title{
THE EMERGENCE OF GLOBAL ADMINISTRATIVE LAW
}

\author{
Benedict Kingsbury, ${ }^{*}$ NiCO KRISCH, ${ }^{* *} \&$ Richard B. STEWART***
}

\section{INTRODUCTION: THE UNNOTICED RISE OF GLOBAL ADMINISTRATIVE LAW}

Emerging patterns of global governance are being shaped by a little-noticed but important and growing body of global administrative law. This body of law is not at present unified-indeed, it is not yet an organized field of scholarship or of practice. The Global Administrative Law Research Project at New York University School of $\mathrm{Law}^{1}$ is an effort to systematize studies in diverse national, transnational, and international settings that relate to the administrative law of global governance. Using ideas developed in the first phases of this project, in this article we begin the task of identifying, among these assorted practices, some patterns of commonality and connection sufficiently deep and farreaching as to constitute an embryonic field of global administrative law. We point to some factors encouraging the development of common approaches, and to mechanisms of learning, borrowing, and cross-referencing, that are contributing to a degree of integration in this field. We also note some major constraints and enduring reasons for non-convergence. We begin to assess the normative case for and against promotion of a unified field of global administrative law, and for and against some specific positions within it. This paper

Copyright ( 2005 by Benedict Kingsbury, Nico Krisch, and Richard B. Stewart

This Article is also available at http://law.duke.edu/journals/lcp.

* Murry and Ida Becker Professor of Law and Director, Institute for International Law and Justice, New York University School of Law.

** Junior Research Fellow, Merton College, Oxford.

*** University Professor, John E. Sexton Professor of Law and Director, Center on Environmental \& Land Use Law, New York University School of Law.

1. Research Project on Global Administrative Law, NYU School of Law Institute for International Law and Justice in conjunction with the Center on Environmental and Land Use Law. Working papers, a bibliography, and project documents appear on the project website at http://www.iilj.org/global_adlaw. This website also includes links to project partners, and to other research projects around the world in related areas. We thank for ideas and for specific comments the many faculty, visiting fellows, and students participating in this project, as well as participants at the Japan Society of International Law Hiroshima Conference, at an NYU Law School faculty workshop, and at an NYU-Oxford Global Law Institute project workshop at Merton College, Oxford University. We acknowledge with gratitude the financial support of the Filomen D'Agostino and Max Greenberg Faculty Research Fund, the Hauser Global Law School Program, and a grant to the IILJ from Carnegie Corporation of New York. 
draws on publications by project contributors and others in this area, ${ }^{2}$ and seeks to carry this collective enterprise forward; but the results remain preliminary.

Underlying the emergence of global administrative law is the vast increase in the reach and forms of transgovernmental regulation and administration designed to address the consequences of globalized interdependence in such fields as security, the conditions on development and financial assistance to developing countries, environmental protection, banking and financial regulation, law enforcement, telecommunications, trade in products and services, intellectual property, labor standards, and cross-border movements of populations, including refugees. Increasingly, these consequences cannot be addressed effectively by isolated national regulatory and administrative measures. As a result, various transnational systems of regulation or regulatory cooperation have been established through international treaties and more informal intergovernmental networks of cooperation, shifting many regulatory decisions from the national to the global level. Further, much of the detail and implementation of such regulation is determined by transnational administrative bodies-including international organizations and informal groups of officials-that perform administrative functions but are not directly subject to control by national governments or domestic legal systems or, in the case of treaty-based regimes, the states party to the treaty. These regulatory decisions may be implemented directly against private parties by the global regime or, more commonly, through implementing measures at the national level. Also increasingly important are regulation by private international standard-setting bodies and by hybrid public-private organizations that may include, variously, representatives of businesses, NGOs, national governments, and intergovernmental organizations.

This situation has created an accountability deficit in the growing exercise of transnational regulatory power, which has begun to stimulate two different types of responses: first, the attempted extension of domestic administrative law to intergovernmental regulatory decisions that affect a nation; and second, the development of new mechanisms of administrative law at the global level to address decisions and rules made within the intergovernmental regimes.

A somewhat different but related issue arises when regulatory decisions by a domestic authority adversely affect other states, designated categories of individuals, or organizations, and are challenged as contrary to that government's obligations under an international regime to which it is a party. Here one response has been the development by intergovernmental regimes of administrative law standards and mechanisms to which national administrations must conform in order to assure their compliance and accountability with the international regime. In order to boost their legitimacy and effectiveness, a number of regulatory bodies not composed exclusively of states-hybrid pub-

2. An extensive bibliography is found in this volume. A Global Administrative Law Bibliography, 68 L. \& CONTEMP. PROBS. 357 (Summer/Autumn 2005). 
lic-private, and purely private bodies-have also begun to adopt administrative law decisionmaking and rulemaking procedures.

These developments lead us to define global administrative law as comprising the mechanisms, principles, practices, and supporting social understandings that promote or otherwise affect the accountability of global administrative bodies, in particular by ensuring they meet adequate standards of transparency, participation, reasoned decision, and legality, and by providing effective review of the rules and decisions they make. Global administrative bodies include formal intergovernmental regulatory bodies, informal intergovernmental regulatory networks and coordination arrangements, national regulatory bodies operating with reference to an international intergovernmental regime, hybrid public-private regulatory bodies, and some private regulatory bodies exercising transnational governance functions of particular public significance.

In proposing such a definition, we are also proposing that much of global governance can be understood and analyzed as administrative action: rulemaking, administrative adjudication between competing interests, and other forms of regulatory and administrative decision and management. Domestic law presumes a shared sense of what constitutes administrative action, even though it may be defined primarily in the negative - as state acts that are not legislative or judicial-and even though the boundaries between these categories are blurred at the margins. ${ }^{3}$ Beyond the domain of the state, no such agreed functional differentiation prevails; the institutional landscape is much more variegated than in domestic settings. Yet many of the international institutions and regimes that engage in "global governance" perform functions that most national public lawyers would regard as having a genuinely administrative character: they operate below the level of highly publicized diplomatic conferences and treaty-making, but in aggregate they regulate and manage vast sectors of economic and social life through specific decisions and rulemaking. Conceptually, we believe, administrative action can be distinguished from legislation in the form of treaties, and from adjudication in the form of episodic dispute settlement between states or other disputing parties. As in the domestic setting, administrative action at the global level has both legislative and adjudicatory elements. It includes rulemaking, not in the form of treaties negotiated by states, but of standards and rules of general applicability adopted by subsidiary bodies. $^{4}$ It also includes informal decisions taken in overseeing and implementing international regulatory regimes. As a matter of provisional delineation, global administrative action is rulemaking, adjudications, and other decisions that are neither treaty-making nor simple dispute settlements between parties. ${ }^{5}$

3. On the German example, see Hartmut Maurer, Allgemeines VerwaltungsRecht (14th ed., 2002).

4. Some forms of global administrative decisionmaking are closely connected with dispute settlement, not least because quasi-judicial organs such as the WTO Dispute Settlement Body also perform important regulatory oversight functions.

5. See Richard B. Stewart, U.S. Administrative Law: A Model for Global Administrative Law?, 68 L. \& CONTEMP. PROBS. 63 (Summer/Autumn 2005). 
In this article, we seek to develop an approach to global administrative action by delineating and elaborating what we believe is a nascent field of global administrative law. We survey major issues and challenges in this nascent field, and begin to sketch elements of a research agenda for its further development. We organize the paper by exploring, seriatim, five kinds of questions that are central to current practice and further work: (1) questions about the basic structural patterns of global administration, and how variance among them is shaping emerging accountability mechanisms; (2) methodological and empirical questions concerning the scope and sources of global administrative law, the mechanisms of accountability, and the doctrinal principles that are currently in place or emerging in practice; (3) normative questions about how to justify and defend such mechanisms; (4) institutional design issues as to how such mechanisms should be designed in order to ensure accountability without unduly compromising efficacy; and (5) positive political theory questions about the emergence and design of such mechanisms and which factors may be conducive to their success.

II

\section{THE Structure of THE Global AdMinistrative SPACE}

The conceptualization of global administrative law presumes the existence of global or transnational administration. We argue that enough global or transnational administration exists that it is now possible to identify a multifaceted "global administrative space" (a concept to which we will return shortly), populated by several distinct types of regulatory administrative institutions and various types of entities that are the subjects of regulation, including not only states but also individuals, firms, and NGOs. But this view is certainly contested. Many international lawyers still view administration largely as the province of the state or of exceptional interstate entities with a high level of integration, such as the European Union. In this view, which is complemented by what has hitherto been the largely domestic or E.U. focus of administrative lawyers, international action might coordinate and assist domestic administration, but given the lack of international executive power and capacity, does not constitute administrative action itself. This view, however, is contradicted by the rapid growth of international and transnational regulatory regimes with administrative components and functions. Some of the most dense regulatory regimes have arisen in the sphere of economic regulation: the OECD networks and committees, the administration and the committees of the WTO, the committees of the G-7/G-8, structures of antitrust cooperation, ${ }^{6}$ and financial regulation performed by, among others, the IMF, the Basle Committee ${ }^{7}$ and the Financial

6. On antitrust, see Eleanor Fox, International Antitrust and the Doha Dome, 43 VA. J. INT'L L. 911, 925-32 (2003).

7. For analysis of the Basle Committee, see David Zaring, International Law by Other Means: The Twilight Existence of International Financial Regulatory Organizations, 33 TEX. INT'L L.J. 281, 287-91 
Action Task Force. Environmental regulation is partly the work of nonenvironmental administrative bodies such as the World Bank, the OECD, and the WTO, but increasingly far-reaching regulatory structures are being established in specialized regimes such as the prospective emissions trading scheme and the Clean Development Mechanism in the Kyoto Protocol. Administrative action is now an important component of many international security regimes, including work of the U.N. Security Council and its committees, and in related fields such as nuclear energy regulation (the IAEA) or the supervision mechanism of the Chemical Weapons Convention. Reflection on these illustrations immediately indicates that the extraordinarily varied landscape of global administration results not simply from the highly varied regulatory subject areas and correlative functional differentiations among institutions, but also from the multi-layered character of the administration of global governance. In this section we seek to provide some conceptual tools for organizing the analysis of these diverse phenomena by identifying the different structures and subjects of global administration and by positing the notion of a global administrative space.

This enterprise in some measure builds on conceptions of international administration and international administrative law that developed from the midnineteenth century and became prevalent in the 1920s and 1930s. The idea of analyzing transnational governance as administration subject to distinctive administrative law principles appears, for instance, in the work of late-nineteenth century social reformers and institution builders, as in Lorenz von Stein's conception of international public health work in administrative terms. ${ }^{8}$ This administrative approach was spurred by the rise of international regulatory institutions, "international unions," dealing with such matters as postal services, navigation, and telecommunications, sometimes with significant powers of secondary rulemaking that did not require national ratification to be legally effective. ' The cooperation of domestic administrative actors that took place in the framework of these unions, and the centrality of domestic actors for the success of the regimes in question, led some authors to adopt broad notions of "international administration" that included both international institutions and domes-

(1998); see also David Zaring, Informal Procedure, Hard and Soft, in International Administration, 5 CHI. J. INT'L L. 547 (2005).

8. Lorenz von Stein, Einige Bemerkungen über das internationale Verwaltungsrecht, 6 JAHRBUCH FÜR GeSETZGebung, Verwaltung UND VOLKSWIRTSCHAFT IM DEUTSCHEN REICH 395 (1882). For discussion of the early history of the field, see José Gascón y Marin, Les transformations du droit administratif international, 34 RECUEIL DES COURS 4, 7-15 (1930); and more recently, CHRISTIAN TIETJE, INTERNATIONALISIERTES VERWALTUNGSHANDELN (2001). On Lorenz von Stein, see FRANK SCHULZ-NIESWANDT, DIE LEHRE VOM ÖFFENTLICHEN GESUNDHEITSWESEN BEI LORENZ VON STEIN (1989).

9. See Paul S. Reinsch, International Administrative Law and National Sovereignty, 3 AJIL 1 (1909); see also Paul Négulesco, Principes du droit international administratif, 51 RECUEIL DES COURS 579 (1935). For a central work developing a conflict of laws approach to administrative law on transborder issues, see KARL NEUMEYER, 4 INTERNATIONALES VERWALTUNGSRECHT (1936). 
tic administrative actors when taking actions with transboundary significance. ${ }^{10}$ These comprehensive approaches, along with the whole idea of administrative elements in international affairs, faded away in most standard international law texts after 1945, ${ }^{11}$ although notable exceptions are to be found in the works of Wilfred Jenks, Soji Yamamoto, and a few others. ${ }^{12}$ Our conceptualization of global administration seeks to revitalize the broader vision that lay behind those earlier approaches.

\section{A. Five Types of Global Administration}

Five main types of globalized administrative regulation are distinguishable: (1) administration by formal international organizations; (2) administration based on collective action by transnational networks of cooperative arrangements between national regulatory officials; (3) distributed administration conducted by national regulators under treaty, network, or other cooperative regimes; (4) administration by hybrid intergovernmental-private arrangements; and (5) administration by private institutions with regulatory functions. In practice, many of these layers overlap or combine, but we propose this array of ideal types to facilitate further inquiry. ${ }^{13}$

10. See Pierre Kazansky, Théorie de l'administration internationale, 9 REVUE GENERALE DE Droit INTERNATIONAL PUBLIC 353, 360 (1902); see also Négulesco, supra note 9, at 589-93. George Scelle, in the first two volumes of his Précis de droit des gens (1932 and 1934), sketched aspects of such an approach, focusing on the double role of national governmental agencies as both national actors and administrators of international action. Scelle had intended to develop this approach in a third volume on international administrative law. See SCELLE, 1 PRÉCIS DE DROIT DES GENS 69 (1932).

11. Notions such as "international administrative unions" continue to be recognized, see, e.g., Rüdiger Wolfrum, International Administrative Unions, in 2 ENCYCLOPEDIA OF PUBLIC INTERNATIONAL LAW 1041 (Rudolf Bernhardt ed., 1995). The "administrative tribunals" of international organizations, and associated review mechanisms, have long been concerned with a narrow but important aspect of international administration relating to the rights of staff members of these organizations and to general issues concerning the international civil service. The significant role these tribunals may play in certain cases is exemplified by the decision of the Administrative Tribunal of the International Labour Organization in Bustani v. Organisation for the Prohibition of Chemical Weapons, Judgment No. 2232, July 16, 2003, available at http:/www.ilo.org/public/english/ tribunal/fulltext/2232.htm. The Tribunal upheld elements of José Bustani's complaint about his dismissal from the post of Director-General of the OPCW, a dismissal that followed confrontations with the United States about inspections of chemical facilities under the OPCW regime; see also Ana Stani, Removal of the Head of a Multilateral Organization-Independence of International Organization and Their Secretariat-Political Interference by Member State in the Operation of International Organization, 98 AJIL 810 (2004).

12. C. Wilfred Jenks, The Proper LAw of International Organisations (1963); Soji Yamamoto, Kokusai gyoseiho no sonritsu kiban ("The Positive Basis of International Administrative Law"), in 76:5 KOKUSAIHO GAIKO ZASSHI ("THE JOURNAL OF INTERNATIONAL LAW AND DIPLOMACY") 1 (1967); see also INTERNATIONAL ADMINISTRATION: ITS EVOLUTION AND CONTEMPORARY APPLICATIONS (Robert S. Jordan ed., 1971); and Hugo J. Hahn, Control Under the Euratom Compact 7 A. J. COMP. L. 23 (1958)

13. On the combination of different layers in E.U. administration see Sabino Cassese, European Administrative Proceedings, 68 L. \& CONTEMP. PROBS. 21 (Winter 2004); see also Giacinto della Cananea, The European Union's Mixed Administrative Proceedings, 68 L. \& CONTEMP. PROBS. 197 (Winter 2004); Edoardo Chiti, Administrative Proceedings Involving European Agencies, 68 L. \& CONTEMP. PROBS. 219 (Winter 2004). 
In international administration, formal inter-governmental organizations established by treaty or executive agreement are the main administrative actors. A central example is the U.N. Security Council and its committees, which adopt subsidiary legislation, take binding decisions related to particular countries (mostly in the form of sanctions), and even act directly on individuals through targeted sanctions and the associated listing of persons deemed to be responsible for threats to international peace. Similarly, the United Nations High Commissioner for Refugees has assumed numerous regulatory and other administrative tasks, such as conducting refugee status determinations and administering refugee camps in many countries. Other examples include the World Health Organization's assessing global health risks and issuing warnings, the Financial Action Task Force's assessing policies against money-laundering and sanctioning violations by specific states of the standards it has adopted, the compliance mechanisms of the Montreal Protocol under which subsidiary bodies of an administrative character deal with non-compliance by Parties to the Protocol, and the World Bank's setting standards for "good governance" for specific developing countries as a condition for financial aid.

Transnational networks and coordination arrangements, by contrast, are characterized by the absence of a binding formal decisionmaking structure and the dominance of informal cooperation among state regulators. This horizontal form of administration can, but need not, take place in a treaty framework. For example, the Basle Committee brings together the heads of various central banks, outside any treaty structure, so they may coordinate on policy matters like capital adequacy requirements for banks. The agreements are non-binding in legal form but can be highly effective. A different example is the pressure WTO law exerts for mutual recognition of regulatory rules and decisions among member states, thus establishing a strong form of horizontal cooperation through which regulatory acts of one state automatically gain validity in another. $^{14}$ National regulators also develop, on a bilateral basis, arrangements for mutual recognition of national regulatory standards or conformity procedures and other forms of regulatory coordination, such as regulatory equivalence determinations. $^{15}$

In distributed administration, domestic regulatory agencies act as part of the global administrative space: they take decisions on issues of foreign or global concern. An example is in the exercise of extraterritorial regulatory jurisdiction, in which one state seeks to regulate activity primarily occurring elsewhere. In some circumstances, such regulation is subject to substantive limitations and even procedural requirements established internationally, as has become evident from the WTO Appellate Body's 1998 ruling in United States-Import

14. See Sidney Shapiro, International Trade Agreements, Regulatory Protection, and Public Accountability, 54 ADMIN. L. REV. 435, 453-57 (2002).

15. See Kalypso Nicolaidis \& Gregory Shaffer, Transnational Mutual Recognition Regimes: Governance without Global Government, 68 L. \& CONTEMP. PROBS. 263 (Summer/Autumn 2005). 
Prohibition of Certain Shrimp and Shrimp Products (Shrimp-Turtle). ${ }^{16}$ But even domestic administration without immediate extraterritorial effects may be part of the global administrative space, especially when it is charged with implementing an international regime. National environmental regulators concerned with biodiversity conservation or greenhouse gas emissions are today often part of a global administration, as well as part of a purely national one: they are responsible for implementing international environmental law for the achievement of common objectives, and their decisions are thus of concern to governments (and publics) in other states, as well as to the international environmental regime they are implementing. Arrangements for mutual recognition of standards and certifications between particular national regulators might also have some of the qualities of distributed administration, although opinions vary sharply as to how best to understand the mosaic of mutual recognition agreements and comparable cooperative approaches.

A fourth type of global administration is hybrid intergovernmental-private administration. Bodies that combine private and governmental actors take many different forms and are increasingly significant. An example is the Codex Alimentarius Commission, which adopts standards on food safety through a decisional process that now includes significant participation by non-governmental actors as well as by government representatives, and produces standards that gain a quasi-mandatory effect via the SPS Agreement under WTO law. Another example is the Internet address protocol regulatory body, the Internet Corporation for Assigned Names and Numbers (ICANN), which was established as a non-governmental body, but which has come to include government representatives who have gained considerable powers, often via service on ICANN's Governmental Advisory Committee, since the 2002 reforms. Determining how administrative law can be shaped or made operational in relation to such bodies is difficult. The involvement of state actors, subject to national and international public law constraints, alongside private actors who are not, and who may indeed have conflicting duties such as commercial confidentiality, threatens a very uneven and potentially disruptive set of controls. The challenge is nevertheless an important one, and sufficiently distinctive that we treat these hybrid bodies as a separate category.

Fifth and finally, many regulatory functions are carried out by private bodies. $^{17} \quad$ For example, the private International Standardization Organization (ISO) has adopted over 13,000 standards that harmonize product and process rules around the world. On a smaller scale, NGOs have come to develop standards and certification mechanisms for internationally traded products, for ex-

16. WTO Appellate Body, United States-Import Prohibition of Certain Shrimp and Shrimp Products, WT/DS58/AB/R Doc. No. 98-3899 (Oct. 12, 1998) [hereinafter Shrimp-Turtle]; see discussion infra Part III.C.3; see also United States-Definitive Safeguard Measures on Imports of Certain Steel Products, WT/DS248/AB/R (2003) [hereinafter U.S. Steel].

17. See generally THE EMERGEnCE OF PRIVATE AUthority In Global GovernanCE (Rodney Bruce Hall \& Thomas J. Biersteker eds., 2002). 
ample fair-trade coffee and sustainably harvested timber. Business organizations have set up rules and regulatory regimes in numerous industries, ranging from the Society for Worldwide Interstate Financial Telecommunications (SWIFT) system for letters of credit, to Fair Labor Association standards for sports apparel production. In national law, such private bodies are typically treated as clubs rather than as administrators, unless they exercise public power by explicit delegation. But in the global sphere, due to the lack of international public institutions, they often have greater power and importance. Their acts may not be much different in kind from many non-binding intergovernmental public norms, and may often be more effective. We cautiously suggest that the margins of the field of global administration be extended to the activities of some of these non-governmental bodies. The ISO provides a good example: not only do its decisions have major economic impacts, but they are also used in regulatory decisions by treaty-based authorities such as the WTO. An example of a private regulatory body that is less connected with state or inter-state action is the World Anti-Doping Agency, an organization connected with the International Olympic Committee, which applies careful due process standards in dealing with athletes suspected of using banned substances, culminating in the review system of the private International Court of Arbitration for Sport. Significant normative and practical problems arise in proposals to extend administrative law approaches to such bodies, although these problems are contextspecific rather than uniform. We believe it is desirable to study such bodies as part of global administration, and to trace similarities as well as differences in mechanisms of accountability developed for public and private bodies.

B. The Subjects of Global Administration: States, Individuals, Corporations, NGOs, and Other Collectivities

Breaking down the domestic-international dichotomy may have further repercussions in the way we think about the subjects of global administration. Traditionally understood, the subjects of international law are states. Correlatively, global governance is the governance of states' behavior with regard to other states. Increasingly however, regulatory programs agreed to at the international level by states are effectuated through measures taken by governments at the domestic level to regulate private conduct. Coordinated regulation of private conduct is often the very purpose of the international scheme in fields such as regulation of pollution or financial practices. In classical theory the domestic regulatory measures are the implementation by states of their international obligations. Private actors are formally addressed only in the implementation stage, and that is solely a domestic matter. But the real addressees of such global regulatory regimes are now increasingly the same as in domestic 
law: namely, individuals (as both moral agents and economic and social actors) ${ }^{18}$ and collective entities like corporations and, in some cases, NGOs. ${ }^{19}$

This characterization is most powerful when international bodies make decisions that have direct legal consequences for individuals or firms without any intervening role for national government action. Examples include certification of CDM projects by the Kyoto Protocol Clean Development Mechanism, UNCHR determinations of individuals' refugee statuses, and certification of NGOs by U.N. agencies as being specifically authorized to participate in their procedures. The notion that private actors are the subjects of global regulation is also evident in much of the regulatory governance accomplished through networks, wherein the national regulatory officials perform both an international-level role, deciding collectively with counterparts on regulatory requirements applicable to private firms (for example, commercial banks), and a domestic-level role in implementing and enforcing those same norms with respect to the regulated firms within their jurisdiction. This is even more evident in the case of private governance arrangements such as ISO, wherein most standards are designed for implementation by private firms, even if they may also be implemented in national law.

In other situations, the aim of the international regime is to achieve desired changes in private conduct by imposing regulatory obligations on states and supervising the manner in which states regulate the private actors subject to their jurisdiction. These arrangements are similar to models of multi-level governance that have been developed to understand the European Union and the "European administrative space." ${ }^{20}$ Examples include the Convention on International Trade in Endangered Species (CITES), the Montreal Protocol on ozone layer depletion, the Basel Convention on hazardous wastes, and the Conventions of the International Labour Organization (ILO). The international administrative bodies responsible for promoting and supervising implementation often play a major regulatory role, outside of and contrary to the classical theory. In many instances, the administrative bodies in question have assumed a mixed public-private governance structure in which firms and NGOs participate along with representatives of states; this builds on the longstanding approach exemplified by the tripartite governance structure of the ILO based on national delegations representing governments, employers, and labor.

In yet other areas, states are the primary subjects of global regulation, which is undertaken to protect or benefit distinct groups of individuals, private market

18. See Stewart, supra note 5. The argument that individuals are the ultimate subjects of legal regulation has long been made by one liberal tradition of international lawyers. See, e.g., J.L. Brierly, Règles générales du droit de la paix, 58 RECUEIL DES COURS 5, 47-52 (1936).

19. For an early approach along such lines, see Négulesco, supra note 9, at 604-05. For tendencies towards a similar conceptualization in the European Union, including by E.U. courts, see della Cananea, supra note 13.

20. See Martin Shapiro, The Institutionalization of European Administrative Space, in THE INSTITUTIONALIZATION OF EUROPE 94 (Alec Stone Sweet et al. eds., 2001); DER EUROPÄISCHE VERWALTUNGSRAUM (Heinrich Siedentopf ed., 2004). 
actors, or social interests. Examples include the "good governance" and rule of law standards and the environmental standards imposed by agencies such as the World Bank as conditions for financial assistance to developing countries, including requirements for environmental impact assessments for development projects.

Finally, in some areas of regulatory administration, such as international security, the classical view that global governance is directed at the behavior of governments toward other governments, rather than toward private actors, still has great force. However, even here the growing privatization of international security activities, like the growing use of private contractors to carry out traditional state functions in situations such as the military occupation of Iraq, is beginning to erode the classical view. ${ }^{21}$

These various examples suggest that differences in the subjects of global administrative regimes - in some cases individuals or firms, in others both states and market actors, in others states with distinct groups of individuals, market actors, NGOs, or social interests as the beneficiaries, and in still others states alone-might depend on differences in the subject area, the objectives of regulation, and the functional characteristics of the regulatory problem. This is a significant issue for future research.

\section{A Global Administrative Space?}

This brief survey of structures and examples indicates that important regulatory functions are no longer exclusively domestic in character and have become significantly transnational, or global. This is especially true in the area of rulemaking, in which genuinely international action combines with action by national regulators in networks of global coordination to supplement, and often determine, domestic action, thus penetrating deeply into domestic regulatory programs and decisions. Further, in more and more cases, global decisions directly affect individuals or firms, as for example in U.N. Security Council decisions on sanctions and anti-terrorism measures, in UNHCR activities, in the Clean Development Mechanism under the Kyoto Protocol, or in the quasiautomatic incorporation in domestic law of decisions by the Financial Action Task Force.

Yet this does not conclusively answer the question whether a distinct global administrative space should be recognized or whether it is still possible and indeed preferable to maintain the classical dichotomy between an administrative space in national polities on the one hand and inter-state coordination in global governance on the other. It is true that the global and the domestic remain po-

21. See Anna Leander, Conditional Legitimacy, Reinterpreted Monopolies: Globalisation and the Evolving State Monopoly on Legitimate Violence, COPRI Working Paper 2002/10, 18, at http://www.ciaonet.org/wps/lea04.pdf; Elke Krahmann, Private Firms and the New Security Governance, 5 CONFlict, SECURITY AND DEVElopMent (forthcoming 2005); Peter W. Singer, War, Profits, and the Vacuum of Law: Privatized Military Firms and International Law, 42 COLUM. J. OF TRANSNAT'L L. 521 (2004). 
litically and operationally separate for many purposes. Nonetheless, the two realms are already closely intertwined in many areas of regulation and administration. The rise of regulatory programs at the global level and their infusion into domestic counterparts means that the decisions of domestic administrators are increasingly constrained by substantive and procedural norms established at the global level; the formal need for domestic implementation thus no longer provides for meaningful independence of the domestic from the international realm. At the same time, the global administrative bodies making those decisions in some cases enjoy too much de facto independence and discretion to be regarded as mere agents of states. Weighing the significance and trajectory of this interconnectedness is a matter of appreciation, on which views differ. In our view, international lawyers can no longer credibly argue that there are no real democracy or legitimacy deficits in global administrative governance because global regulatory bodies answer to states, and the governments of those states answer to their voters and courts. National administrative lawyers can no longer insist that adequate accountability for global regulatory governance can always be achieved through the application of domestic administrative law requirements to domestic regulatory decisions. We argue that current circumstances call for recognition of a global administrative space, distinct from the space of inter-state relations governed by international law and the domestic regulatory space governed by domestic administrative law, although encompassing elements of each. ${ }^{22}$

This multifaceted administrative space incorporates the five different types of international or transnational administrative bodies described above. In this space, states, individuals, firms, NGOs, and other groups or representatives of domestic and global social and economic interests who are affected by, or otherwise have a stake in, global regulatory governance, interact in complex ways. The space is characterized by distinct features and dynamics that call for independent positive and normative study and theorizing. These efforts must necessarily build on, but at the same time transcend, both traditional international law, and domestic administrative law - an insight foreshadowed in writings on international administrative law in the early twentieth century, but neglected since. $^{23}$ The relative autonomy and distinct character of this global administrative space, and its increasingly powerful decisionmaking bodies, lead us to argue for the recognition and further development of new and distinct principles and mechanisms of accountability through a global administrative law. The practical result of such developments is that lawyers representing governments, international organizations, firms, individuals, and NGOs concerned with a growing proportion of regulatory decisions will have to become familiar with the institutions and activities within the global administrative space and participate in the building of a global administrative law to help govern that space.

22. On similar approaches in E.U. jurisprudence, see Cassese, supra note 13, at 34-36.

23. For an emphasis on the roots of international administrative law in both public law and international law, see, e.g., Négulesco, supra note 9, at 592-99; see also Kazansky, supra note 10, at 365. 
Our espousal of the notion of a global administrative space is the product of observation, but it inevitably has potential political and other normative implications. On the one hand, casting global governance in administrative terms might lead to its stabilization and legitimation in ways that privilege current powerholders and reinforce the dominance of Northern and Western concepts of law and sound governance. On the other hand, it might also create a platform for critique. As the extent of global administrative government becomes obvious (and framing global regulation in traditional terms of administration and regulation exposes its character and extent more clearly than the use of vague terms such as governance), ${ }^{24}$ the more resistance and reform may find points of focus. Thus, from the perspective of smaller developing countries, global regulatory institutions including the WTO, IMF, World Bank, and U.N. Security Council might already appear to be "administering" them at the bidding of the industrialized countries, which are generally subject to far less intrusive external regulation. Confronting these issues in administrative terms may highlight the need to devise strategies for remedying unfairness associated with such inequalities.

\section{III}

\section{THE EMERGING GLOBAL AdMinistrative LAW}

\section{A. The Scope of Global Administrative Law}

Understanding global governance as administration allows us to recast many standard concerns about the legitimacy of international institutions in a more specific and focused way. It provides useful critical distance on general, and often overly broad, ${ }^{25}$ claims about democratic deficits in these institutions. It also shifts the attention of scholars of global governance to several accountability mechanisms for administrative decisionmaking, including administrative law, that in domestic systems operate alongside, although not independently from, classical democratic procedures such as elections and parliamentary and presidential control. This inquiry usefully highlights the extent to which mechanisms of procedural participation and review, taken for granted in domestic administrative action, are lacking on the global level. At the same time it invites development of institutional procedures, principles, and remedies with objectives short of building a full-fledged (and at present illusory) global democracy.

In this light, global administrative law draws together different areas of law that pertain to global administration but have long been treated separately, of-

24. See Michel Foucault, Governmentality, in THE FOUCAULT EFFECT: STUDIES IN GoVERnMENTALITY 87 (Graham Burchell et al. eds., 1991); see also Christian Joerges, The Turn to Transnational Governance and its Legitimacy Problems: The Examples of Standardization and Food Safety, at http://www.law.nyu.edu/kingsburyb/spring04/globalization/Joerges \%20Draft $4 \% 20 \% 20 \mathrm{~g} \%$ $20 \mathrm{Feb} \% 2004$.doc.

25. See Andrew Moravcsik, Is there a 'Democratic Deficit' in World Politics? A Framework for Analysis, 39 GOVERNMENT AND OPPOSITION 336 (2004). 
ten for conceptual reasons. ${ }^{26}$ It includes, as one component, the longstanding field of "international administrative law," a term used mainly to denote the rules, procedures, and institutions through which international organizations deal with employment disputes and other internal matters. It also encompasses the specific interpretation by Karl Neumeyer and others of "international administrative law" as the body of national rules that govern the effects of a foreign state's administrative acts in that state's legal order. ${ }^{27}$ But our conception of global administrative law is much broader, and it gets closer to Paul Négulesco's 1935 approach which sees international administrative law as "a branch of public law that, examining the legal phenomena which together constitute international administration, seeks to discover and specify the norms that govern this administration and to systematize them., ${ }^{28}$ In our approach, global administrative law effectively covers all the rules and procedures that help ensure the accountability of global administration, and it focuses in particular on administrative structures, on transparency, on participatory elements in the administrative procedure, on principles of reasoned decisionmaking, and on mechanisms of review.

Direct analogies between national and transnational administrative law must be viewed with great caution. Nevertheless, the sociology of legal professional formation dominated by national legal training means that the project of global administrative law is likely in practice to include, in its constructive aspect, efforts to identify, design, and help build transnational and global structures to fulfill functions at least somewhat comparable to those administrative law fulfills domestically, and to reform domestic administrative law to enable it to deal with the increasingly global character of regulation. Definitions of administrative law in continental Europe are usually taxonomical rather than normative, treating the subject as covering all rules binding on administrative actors, except for those of a constitutional nature. ${ }^{29}$ If seen in this same taxonomical way, the field of global administrative law could encompass the totality of global rules governing administrative action by the five different types of administrative bodies set forth above. This would include substantive law that

26. See the intricate conceptual distinctions in Karl Neumeyer, Internationales Verwaltungsrecht: Völkerrechtliche Grundlagen, in 1 WÖRTERBUCH DES VÖLKERRECHTS UND DER DIPLOMATIE 577, 577-81 (Karl Strupp ed., 1924); see also Gascón y Marin, supra note 8, at 9-24.

27. See Neumeyer, supra note 26; see also Gerhard Hoffmann, Internationales Verwaltungsrecht, in BESONDERES VERWALTUNGSRECHT 781 (Ingo von Münch ed., 6th ed. 1982).

28. See Négulesco, supra note 9 , at 593.

29. See generally Maurer, supra note 3. The study of domestic administrative law illuminates the subject's normative implications as well as its political functions. Historically, the political function has by no means been the same in different political systems: in the nineteenth century, administrative law came about in different ways and for different reasons in democratic systems such as the United Kingdom or the United States than in monarchical settings prevalent in much of continental Europe. These differences in origins and in attitudes towards the executive branch have continuing repercussions. Inquiry into the diverse traditions of administrative law is thus of great relevance to global administrative law. See Peter L. Lindseth, The Paradox of Parliamentary Supremacy: Delegation, Democracy, and Dictatorship in Germany and France, 1920s-1950s, 113 YALE L.J. 1341 (2004). 
defines the powers and limits of regulators, like human rights treaties and case law defining the conditions under which state organs can interfere with individual liberties. ${ }^{30}$ Négulesco's definition cited above, like several of the early approaches to international administrative law, would indeed reach that far. ${ }^{31}$ However, conceiving the field in such broad terms would likely generate an unmanageable research agenda at this early stage in its development and would obfuscate the normative commitments entailed in work on global administrative law, commitments that must be explicitly formulated in order to be tested and contested. The focus of the field of global administrative law is not, therefore, the specific content of substantive rules, but rather the operation of existing or possible principles, procedural rules, review mechanisms, and other mechanisms relating to transparency, participation, reasoned decisionmaking, and assurance of legality in global governance.

\section{B. Sources of Global Administrative Law}

The formal sources of global administrative law include the classical sources of public international law-treaties, custom, and general principles-but it is unlikely that these sources are sufficient to account for the origins and authority of the normative practice already existing in the field. Only rarely do treaties directly address issues of administrative law. Insofar as they spell out principles of administrative procedure, they are usually addressed to and binding on states, not international institutions or intergovernmental networks of national officials. Customary international law is still generally understood as being formed primarily by state action and thus for the time being does not fully incorporate the relevant practice of non-state actors, such as global administrative bodies. Finally, the use of "general principles of law" as a source of international law has been limited mainly to internal needs of international institutions or to norms on which there is a high degree of worldwide convergence. The acceptance of general principles in the practice of formal international law has been low and is unlikely to be extended quickly to the diverse and fragmented contexts of global administration.

It may be that a better account of the legal sources of existing normative practice in global administration could be grounded in a revived version of ius gentium that could encompass norms emerging among a wide variety of actors and in very diverse settings, rather than depending on a ius inter gentes built upon agreements among states. ${ }^{32}$ This approach would mirror, to some extent, law-making procedures in other fields of law beyond the state, such as the lex mercatoria, based on the practices of commercial actors worldwide. ${ }^{33}$ Yet the foundations for possible development of a ius gentium of global administration

30. For a similarly broad approach, see TIETJE, supra note 8 .

31. See Kazansky, supra note 10, at 361; see also Gascón y Marin, supra note 8, at 20 and passim.

32. Benedict Kingsbury, The Administrative Law Frontier in Global Governance, 99 PROC. AM. SOC. INT'L L. (forthcoming 2005).

33. See, e.g., Global LAW Without A State (Gunther Teubner ed., 1997). 
are still uncertain. If it is proposed to reflect not a natural law approach but one founded upon practice, uncertainty remains about the basis for determining such norms and their legal status. That general principles of law require such a high convergence of legal systems reflects a strong commitment to inclusiveness, and to preventing impositions by one group of states on the rest. The ius gentium, however attractive a category it may be for global administrative law, will have to face this challenge too.

Yet even among the traditional sources of public international law, there might be room for development of norms relevant to global administrative law. In the case of treaty law, it might be possible to adopt the approach developed by the European Court of Human Rights (ECtHR), which has had to deal with the problem that the European Convention on Human Rights (ECHR) does not formally bind intergovernmental organizations or the European Union. The ECtHR requires member states to ensure that the institutions on which they confer powers provide a level of protection equivalent to the protection provided by the ECHR. Applying such an approach more broadly would supply at least a basic set of standards for global administrative bodies, but it would not solve problems of how to transplant or adapt rich sets of domestic norms to transnational and inter-state institutions, much less hybrid private-public or purely private bodies.

A final problem of sources concerns the status of domestic law. Domestic law is a controlling source of law for domestic administration and thus for national administrative agencies either implementing global law or acting as a part of global administrative structures, or both. Domestic courts may also provide a forum for redress when global administrative bodies act directly on private parties. Through these means, domestic law can help ensure accountability of global administration; and a subtle architecture of accountability centered on domestic mechanisms might be a means to reflect the varying normative commitments of each national society and thus accommodate diversity. ${ }^{34}$ Yet domestic mechanisms established and operated according to local predilections might not meet the functional needs for a degree of global commonality in principles and mechanisms, and for responsiveness to the particular features of specific global administrative regimes. Conflicts between domestic law, particularly constitutional law, and these global needs might be difficult to resolve except by pragmatic temporary accommodations. It is too soon to know how the regular and robust application of domestic law to national participation in transnational or global administrative bodies, or directly to decisions of such bodies, would affect the functioning of these bodies. ${ }^{35}$ If all their participants

34. See AnNe-Marie Slaughter, A NeW World Order (2004).

35. See Stewart, supra note 5. On the application of U.S. environmental impact assessment procedures to the United States' ratification of NAFTA and the WTO Uruguay Round agreements, see Matthew Porterfield, Public Citizen v. United States Trade Representative: The (Con)Fusion of APA Standing and the Merits Under NEPA, 19 HARV. ENVTL. L. REV. 157 (1995); James Salzman, Seattle's Legacy and Environmental Reviews of Trade Agreements, 31 ENVTL. L. 501 (2001). On the balance to be struck in administrative law proceedings in U.S. courts between upholding international law rules 
were subject to diverse national requirements, procedural as well as substantive, the bodies might have great difficulty operationalizing the commonality necessary for effective regulation and management. Varying domestic controls might also hamper the ability of domestic regulatory officials to participate effectively in global regulatory decisionmaking. Since the traditional dualist separation between the domestic and the international is not sustainable in the integrated global administrative space, the relationship between these requires both continuous pragmatic readjustment and deeper re-theorizing.

Even if agreement were reached on identifying the formal sources of global administrative law, in terms of either traditional international law or a revived ius gentium approach, it is unlikely that a definitive and detailed body of rules and principles governing global administration could presently be formulated, even in relation to formal intergovernmental arrangements. Written intergovernmental instruments concerning such norms are scattered and relatively sparse, the practices of global administrative bodies are fragmented, and formal domestic norms vary considerably even if some convergence is occurring. Hybrid and private global regulatory arrangements are not directly subject to many of these rules and principles, and the status of the emerging administrative legal principles and practices in relation to such hybrid and private systems is largely undetermined. Moreover, under a ius gentium approach, disagreement is inevitable about whose practices to count and whose not to count for the emergence of a rule, and as to how much consistent practice might be necessary to generate a strong pull for adhesion. Should the adoption (or nonadoption) of accountability mechanisms in an international institution count more toward (or against) a new norm than adoption (or non-adoption) in an informal inter-governmental network or in a hybrid institution with private participation? Such questions of methodology require considerable future work.

C. Institutional Mechanisms for the Application and Development of Global Administrative Law: A Taxonomy

1. Domestic Institutions as Checks on Global Administration

Given the absence of genuinely international accountability mechanisms in most global administrative regimes, domestic institutions have often taken the lead in trying to check the global administration. This is most obvious in attempts by domestic courts to establish their jurisdiction over the action of international institutions. Thus, in a landmark decision in 2000, the Bosnian Constitutional Court decided it could review certain decisions by the Office of the

and according deference to a U.S. government agency when the agency's action is in conflict with a WTO ruling, see Jane A. Restani \& Ira Bloom, Essay, Interpreting International Trade Statutes: Is the Charming Betsy Sinking?, 24 FORDHAM INT'L L.J. 1533 (2001), who argue courts should be more deferential to the agency if the agency has followed notice-and-comment procedures or other due process safeguards. Id. at 1543-45. 
High Representative in Bosnia. ${ }^{36}$ The High Representative derived his powers from the 1995 Dayton Agreement (the peace treaty signed after the Bosnian war and endorsed by the Security Council), and an annex to the Agreement, which provided that the High Representative was the final arbiter. ${ }^{37}$ However, the Constitutional Court held that when acting as a de facto domestic official, rather than as an international official, the High Representative was not above the Constitution, and his acts could be reviewed accordingly. ${ }^{38}$ In another variant of this approach, individuals in Europe have brought actions in domestic courts challenging E.U. regulations implementing U.N. Security Council sanctions. In one of these cases, three Swedish citizens of Somali descent argued to the European Court of First Instance (CFI) that they had been targeted by the Council mistakenly and without due process, and that the implementing E.U. regulations were accordingly unlawful. ${ }^{39}$ The CFI rejected their application for provisional relief on narrow grounds, but reserved judgment on the merits. ${ }^{40}$ Soon thereafter, the Security Council's sanctions committee decided to strike two of the claimants from the list and to establish a general procedure, in which individuals can, through a national government, present a demand to be delisted and their reasons for it. ${ }^{41}$

These two examples of court involvement in checking international institutions at the behest of litigants asserting violations of their individual procedural and substantive rights are comparable to efforts by domestic courts in several European countries since the 1970s to rein in the activities of the European Communities. ${ }^{42}$ They are also comparable to decisions of the ECtHR asserting limits on the delegation of powers to international organizations in order to safeguard individual rights. In various decisions, the Court has recognized that states parties to the ECHR will often not be able to ensure the full extent of

36. See Case U9/00 (Constitutional Court of Bosnia and Herzegovina) (Nov. 3, 2000) [hereinafter Case U9/00] (evaluating the Law on State Border Service), at para. 9.

37. See Dayton Agreement, supra note 2, Annex 10, art. II; see also S.C. Res. U.N SCOR, 50th Sess. U.N. Doc./RES/1031, pp. 26-27 (1995).

38. Case U9/00, at para. 9. See Carsten Stahn, International Territorial Administration in the Former Yugoslavia: Origins, Developments and Challenges Ahead, 61 ZEITSCHRIFT FÜR AUSLÄNDISCHES ÖFFENTLICHES RECHT UND VÖLKERRECHT 107, 158-59, 167-71 (2001).

39. Case T-306/01 R. Aden v. Council of the Eur. Union, 2002 E.C.R. II-02387 (application for interim measures).

40. Order of the President of the Court of First Instance of May 7, 2002, at http://europa.eu.int/eurlex/pri/end/oj/dat/2002/c_191/c_19120020810en00250026.pdf (last visited March 25, 2005) (rejecting application for interim measures because there was no urgency).

41. For the Security Council's general procedure see Guidelines of the Security Council Committee Established Pursuant to Resolution 1267 (1999) for the Conduct of its Work, Nov. 7, 2002 as amended April 10, 2003, at http://www.un.org/Docs/sc/committees/1267/1267_guidelines.pdf. For commentary on the de-listing decision, see Per Cramér, Recent Swedish Experiences with Targeted U.N. Sanctions: The Erosion of Trust in the Security Council, in REVIEW OF THE SECURITY COUNCIL BY MEMBER STATES 85, 94-95 (Erika de Wet \& André Nollkaemper eds., 2003); see also David Dyzenhaus, The Rule of (Administrative) Law in International Law, 68 L. \& CONTEMP. PROBS. 127 (Summer/Autumn 2005).

42. See Mattias Kumm, Who is the Final Arbiter of Constitutionality in Europe? Three Conceptions of the Relationship Between the German Federal Constitutional Court and the European Court of Justice, 36 COMMON MARKET L. REV. 351 (1999). 
ECHR protection when they participate in international organizations, but it has insisted that they ensure a roughly equivalent standard. On this basis it has, for example, qualified participation of Member States in the European Union ${ }^{43}$ and indicated limiting considerations for states granting immunity to the European Space Agency in national courts. ${ }^{44}$

On a more conventional basis, domestic courts have reviewed decisions of global administrative bodies of a private character. Here, the rules of private international law apply, including rules reflecting domestic public policy, and domestic courts may be presumptively willing to exercise jurisdiction. For example, the international sports regime of the IOC and the related International Court of Arbitration for Sport has had to convince domestic courts that their decisions in anti-doping matters meet standards of due process in order to have them recognized in domestic law.

Courts are by no means the only domestic institutions involved in making global administration more accountable. In the United States, for example, some federal regulatory officials afford notice and comment when participating in international standard-setting on certain topics. ${ }^{45}$ In such cases, participation of interested persons in administrative proceedings is moved into a phase usually considered as preparatory. This ensures that the participation comes in time to affect international negotiations among regulators that result in decisions that will later be implemented in, or will powerfully influence, domestic regulatory law. ${ }^{46}$ Likewise, parliaments have in some cases begun to extend their oversight over administrative action to participation by national officials in global administrative networks. Thus, the U.S. Congress requires reports from U.S. regulatory agencies before agreeing to recommendations of financial regulatory groups, such as the Basle Committee. ${ }^{47}$ Thus far, however, these types of efforts are episodic and fragmented. They are often driven by particular controversies, so that some problems are neglected, and others extensively addressed. In some cases, multiple legislative committees, judicial bodies, and international inquiry committees might all pursue the same matter, usually with accompanying media attention, as happened with the investigations from 2003 onward into the U.N. Oil-for-Food program in Iraq, and the resulting recommendations for reform of U.N. governance processes. Many legal problems af-

43. See Matthews v. United Kingdom, App. No. 24833/94, 28 Eur. H.R. Rep. 361, para. 32 (1999) (affirming the continuing responsibility of states parties to the European Convention on Human Rights [hereinafter Convention] after they transfer competences to an international organization, like the European Communities, that are not directly bound by the Convention).

44. Waite and Kennedy v. Germany, App. No. 26083/94, 30 Eur. H.R. Rep. 261, para. 68 (1999) (stating that a "material factor" in determining whether the Convention permits Germany to grant the European Space Agency immunity from German courts is whether the applicants have a reasonable alternative means to protect their rights under the Convention). In this case, the Court found that the applicants did have alternative means of legal process available to them and thus upheld the grant of immunity. $I d$. at para. 73 .

45. Stewart, supra note 5.

46. See Stewart, supra note 5.

47. See Zaring, Informal Procedure, supra note 7, at 598. 
fecting such oversight have not yet been adequately addressed, including rules about the admissibility in one process of evidence obtained in another, complex and sometimes unsatisfactory rules about immunities, and principles of allocation and priority between national and international processes. National measures often have the (sometimes intentional) effect of obstructing effective oversight of global governance. While national controls play an increasingly important positive role, coherent patterns in the use of domestic institutions to check administration by transnational and international bodies are not yet in place.

2. Internal Mechanisms Adopted by Global Institutions for Participation and Accountability

In the face of public and governmental criticism, challenges from domestic institutions, and efforts by participating states and the managers of global administrative bodies to strengthen controls over their operations, global administrative bodies have instituted their own accountability mechanisms. The establishment by the Security Council of a limited administrative procedure for the listing and de-listing of individuals targeted by U.N. sanctions illustrates the trend. This procedure, adopted in part in response to domestic court review of domestic implementation of listing decisions, is highly problematic because listed persons are afforded no procedural rights, but must rely on their state of residence or citizenship to pursue their cause. However, it at least introduces some requirements for reasoned decisionmaking and review into the work of Security Council committees, which usually consider themselves purely political bodies, in no way comparable to administrative agencies. ${ }^{48}$

An innovative genre of more robust administrative mechanisms is exemplified by the World Bank Inspection Panel. The Panel procedure was initially established in part to improve compliance of World Bank staff with internal directives, such as Bank guidelines ensuring that Bank-funded projects are environmentally sound. The procedure thus allows the Board to exercise an additional control on the day-to-day administration of the Bank management. But the Panel also plays an important function for affected individuals and groups in providing a forum in which to challenge compliance of the World Bank with its project-related policies. The Panel only has the power of issuing reports and recommendations, and cannot halt or modify non-conforming projects. Moreover, the grounds for such challenges are limited to allegations of non-compliance with the World Bank's own policies and thus do not extend to international law in general; but this limitation has frayed on occasion, and might turn out not to be sustainable. The Inspection Panel model has been

48. See Peter Gutherie, Security Council Sanctions and the Protection of Individual Rights, 60 N.Y.U. ANN. SuRV. AM. L. 491, 512-14 (2004). 
adopted, with variations including greater powers to promote an amicable settlement, in several regional development banks. ${ }^{49}$

Some intergovernmental networks have also moved to establish greater procedural transparency and participation, a striking development for regulatory networks whose informality is often their main advantage. For example, the Basle Committee of central banks opened more widely the process leading up to the drafting of a new Basle capital adequacy accord (Basle II), with comments invited from interested parties. ${ }^{50}$ Similar developments have taken place within the OECD after the need for greater procedural legitimacy of its work was highlighted by the failure of the Multilateral Agreement on Investment. In some areas of its work the OECD has now instituted notice-and-comment procedures, and has encouraged broader public participation directly or through mechanisms in each of the member states. ${ }^{51}$ Another organization with a noticeand-comment procedure is the World Organisation for Animal Health (OIE), which develops standards for animal health applicable under the SPS Agreement. The Financial Action Task Force also invites outside input in its rulemaking efforts and allows for comments by governments of jurisdictions that are under consideration for inclusion in its list of non-cooperating countries and territories and are thus subject to some form of sanction. ${ }^{52}$

The objective of strengthening participation in global administration has increasingly been pursued, although with contested results, by the direct inclusion of NGOs in decisionmaking processes, for example within the Codex Alimentarius Commission. ${ }^{3}$ NGOs have also formed more-or-less cooperative regulatory governance partnerships with corporations. On certain labor and environmental standards, for example, corporations have sought to integrate NGOs into what had previously been purely self-regulatory structures, in order to enhance the legitimacy of the standards and certification mechanisms established by these structures. ${ }^{54}$ In some instances these arrangements assume a hybrid character, operating under the aegis of international administrative bodies such as U.N. agencies. ${ }^{5}$

49. See Demanding ACCOUntability: Civil-Society Claims AND THE World BAnK INSPECTION PANEL (Dana Clark et al. eds., 2003); see also THE INSPECTION PANEL OF THE WORLD BANK: A DifFERENT COMPLAINTS PROCEDURE (Gudmundur Alfredsson \& Rolf Ring eds., 2001).

50. See Zaring, Informal Procedure, supra note 7, at 557.

51. See James Salzman, Decentralized Administrative Law in the Organization for Economic Cooperation and Development, 68 L. \& CONTEMP. PROBS. 189 (Summer/Autumn 2005).

52. Information about the Financial Action Task Force's methods is available at http://www.fatfgafi.org/pages/0,2966,en_32250379_32237277_1_1_1_1_1,00.html.

53. See CODEX AlimentARIUS COMMISSION, ALINORM 03/25/3: REPORT OF THE EVALUATION OF THE CODEX ALIMENTARIUS AND OTHER FAO AND WHO FOOD STANDARDS WORK (2002).

54. See HARM SCHEPEl, The CONSTITUtion OF Private Governance. Product STANDARDS IN THE REGULATION OF INTEGRATING MARKETS (2004).

55. See John Ruggie, Taking Embedded Liberalism Global: The Corporate Connection, in TAMING GlobalizATIOn: FRONTIERS OF GovernanCE 93, 105-06 (David Held \& Mathias Koenig-Archibugi eds., 2003). 


\section{Global Disciplines on Distributed Administration}

The third mechanism of the emerging global administrative law establishes checks for coordinated domestic administration, or, in the terminology introduced here, for the distributed element in global administration. In order to ensure that domestic regulators act as participants in the global regime rather than merely as national actors, intergovernmental agencies have promoted global norms to govern not only the substance of domestic regulation, but also the decisional procedures followed by domestic regulatory agencies when applying a global norm or when subject to its strictures. In effect, these procedural requirements place domestic regulatory bodies and officials in an additional role as agents of the relevant global regime and seek to make them in some way responsible for compliance with it. ${ }^{56}$ These requirements are designed to protect the interests of other states, individuals, and firms subject to regulation, as well as broader social and economic interests affected by the regime by providing them with procedural means to ensure the fidelity of domestic regulators to global administrative norms designed to protect their rights or concerns.

The WTO Appellate Body's first ruling in the Shrimp-Turtle case was a striking effort to promote forum state protection of the interests of affected foreign states. ${ }^{57}$ The Appellate Body ruled that in order for process-based import restrictions to be sustainable under the GATT Article XX exceptions, a state must show that the countries and foreign producers affected were provided with some form of due process. ${ }^{58}$ Thus, international norms required domestic administrative procedure to refocus its pursuit of accountability in order to help ensure that domestic regulators take into account the relevant external constituencies.

Other elements of WTO law, including the GATS, also require changes in domestic administrative procedures. For example, in the telecommunications sector, the model of independent regulatory agencies has been introduced; here the procedure mainly serves to better implement the substantive goals behind global telecommunications regulation. ${ }^{59}$ This is also the rationale behind the far-reaching arbitral review established under investment treaties, via the ICSID system, and by NAFTA. Under such mechanisms, investors can challenge administrative action of the host state before international arbitral tribunals if they believe their rights under the relevant investment treaty have been violated. Increasingly, decisions of these tribunals have extended procedural, as well as substantive, limitations on domestic regulators. This gives investors a

56. Slaughter discusses the dual national and global roles of national public officials in A NEW WORLD ORDER, supra note 34.

57. See Shrimp-Turtle, supra note 16.

58. Id. For commentary see Giacinto Della Cananea, Beyond the State: the Europeanization and Globalization of Procedural Administrative Law, 9 EUROPEAN PUBLIC LAW 563 (2003); see also Sabino Cassese, Global Standards for National Administrative Procedure, 68 L. \& CONTEMP. PROBS. 109 (Summer/Autumn 2005).

59. Markus Krajewski, National Regulation and Trade Liberalization in SERVICES 164-78 (2003). 
very powerful tool, probably not always balanced by sufficient representation of public and other interests. Central review of domestic administrations by regional and global bodies also occurs under human rights treaties. Using rightsbased criteria, the European Court of Human Rights scrutinizes domestic administration for conformity with the European Convention on Human Rights, and it has also developed a rich jurisprudence on domestic administrative procedures, especially on domestic review mechanisms. ${ }^{60}$

For many developing countries, probably the most influential examples in this category are the Bretton Woods institutions. The World Bank's policies on good governance, whether designated as "advice" or as conditions of financial aid to developing countries, have generated extensive codes of principles and rules for the organization and procedures of domestic administration-ranging from measures to combat corruption to practices of greater transparency and procedural guarantees for market actors. ${ }^{61}$ Given the dependence of many countries on aid and external finance, these World Bank norms have transformed, or are in the process of transforming, domestic administration in large parts of the world. Comparable conditions imposed by the IMF on financial assistance to developing countries have had similar effects.

\section{Doctrinal Features of Global Administrative Law: Emerging Principles and Requirements}

In addition to its variety of institutional mechanisms, global administrative law comprises some basic legal principles and requirements of both a procedural and substantive character. Given the fragmentation of practice in global administration and the limited state of integrated knowledge about it, we cannot here venture claims about the doctrinal elements governing this field as a whole. But some candidates can be preliminarily identified, even though their reach may at present be limited. It will be a central task for further research to show the extent to which these and other elements are in fact reflected in global administrative practice, and the extent to which they could be applied or adapted to areas of international or transnational regulation, in which administrative law is currently rudimentary or non-existent.

\section{Procedural Participation and Transparency}

In domestic settings, the right of affected individuals to have their views and relevant information considered before a decision is taken is one of the classical elements of administrative law. Versions of such a principle are increasingly applied in global administrative governance, as a few examples illustrate. Regarding administrative action by one state affecting another, the WTO Appellate Body observed in the Shrimp-Turtle case that the United States had pro-

60. See generally Henri Labayle et al., Droit administratif et Convention européenne des droits de l'homme, 11 REVUE FRANÇAISE DE DROIT ADMINISTRATIF 1172 (1995).

61. See Ngaire Woods \& Amrita Narlikar, Governance and the Limits of Accountability: The WTO, the IMF and the World Bank, 53 INT'L SOC. SCI. J. 569 (2001). 
vided none of the states whose exports of shrimp products to the United States had been curtailed by domestic U.S. administrative regulations with a "formal opportunity to be heard, or to respond to any arguments that may be made against it," and required the United States to provide mechanisms for procedural participation. ${ }^{62}$ Regarding administrative action by an intergovernmental body affecting particular states, even non-Member States have been provided an opportunity for comment before they are placed on a list of non-compliant states by the Financial Action Task Force. ${ }^{63}$ Regarding individuals, an opportunity to be heard is emphasized in the IOC's recent World Anti-Doping Code, in which normative principles of administrative law are applied to constrain administrative decisionmaking in a private institutional setting. In contrast, in the context of U.N. Security Council economic sanctions against states that will affect individuals and groups living or doing business within those states, no structure has been established for participation by such potentially affected groups prior to a sanctions decision, although in the special case of people listed for asset-freezing under anti-terrorism resolutions, a limited form of subsequent challenge and review has been instituted.

Participation in global administrative proceedings has not been confined to individuals or states targeted by decisions. In the area of standard-setting and rulemaking, several bodies, such as the Codex Alimentarius Commission, have sought to include in their work NGOs representing affected social and economic interests. ${ }^{64}$ Domestic regulators, too, have begun to give notice of proposed standards being considered in global negotiations in which they participate. However, participation rights in rulemaking have been afforded in only a limited number of instances and areas.

Decisional transparency and access to information are important foundations for the effective exercise of participation rights and rights of review. They also promote accountability directly by exposing administrative decisions and relevant documents to public and peer scrutiny. Increasingly, international bodies such as the World Bank, the IMF, and the WTO are responding to criticism of decisionmaking secrecy by providing wider public access to internal documents. Involvement of NGOs in decisionmaking, as in the Codex example, is another means of promoting transparency. Regulatory networks, such as the Basle Committee and IOSCO, have developed web sites that contain abundant material on internal decisionmaking and the information and considerations on which decisions are based. Similar steps have been taken by a variety of hybrid public-private global regulatory networks, such as those dealing with sustainable forestry certification. These developments are generally voluntary for the regime in question. There have also been some international agreements pro-

62. Shrimp-Turtle, supra note 16, at para. 180 et seq.

63. See Report of the Financial Action Task Force on Non-Cooperative Countries or Territories, at http://www.fatf-gafi.org/dataoecd/57/22/33921735.pdf, at para. 41.

64. Steve Suppan, Consumers International's Decision-Making in the Global Market, Codex Briefing Paper (2004), at http://www.tradeobservatory.org/library.cfm?RefID=36988. 
viding for transparency at both the level of global regimes and of domestic administration, especially in the environmental field. The public access to environmental information provisions of the Aarhus Convention, which apply both to international organizations and to states that are parties, is a prominent example. $^{65}$ The WTO, the World Bank, and the IMF are examples of international bodies that have developed transparency requirements for national administrations.

\section{Reasoned Decisions}

The requirement of reasons for administrative decisions, including responses to the major arguments made by the parties or commenters, has been extended from domestic law into some global and regional institutions. The international practice outside adjudicatory tribunals is relatively thin, partly because the number of decisions by global administrative agencies directly affecting particular persons is, although growing, still limited. The Shrimp-Turtle decision and subsequent WTO case law are of central importance in establishing principles of reasoned decisionmaking for global administrative regulation, as is the Security Council's decision to require, at least internally, some kind of justification by the proposing country before an individual is included in the lists of those whose assets are to be frozen. Similarly, in the global anti-doping regime, a written, reasoned decision has been made a requirement for measures against a particular athlete. In the area of rulemaking, however, it does not seem to have become a practice of global administrative bodies to give reasons, though some organizations provide them in order to strengthen the acceptability of their actions to affected interests. The Basle Committee, for example, has established a web-based dialogic process in developing its new capital adequacy requirements for banks; drafts are posted, comments are invited, and reasons are given by the Committee in connection with new and revised drafts. The World Bank's International Finance Corporation has followed a similar procedure for revision of its safeguards policies.

\section{Review}

An entitlement to have a decision of a domestic administrative body affecting one's rights reviewed by a court or other independent tribunal is among the most widely accepted features of domestic administrative law, and this is to some extent mirrored in global administration. ${ }^{66}$ An entitlement to review by national authorities was mentioned in the Shrimp-Turtle decision. ${ }^{67}$ Acceptance of the importance of review is reflected in the establishment of the World Bank Inspection Panel, and also in the right of appeal to the Court of Arbitration for

65. Convention on Access to Information, Public Participation in Decision-Making, and Access to Justice in Environmental Matters, June 25, 1998, 38 I.L.M. 517 (entered in force Oct. 30, 2001) [hereinafter Aarhus Convention].

66. For an early, though brief, discussion, see Négulesco, supra note 9, at 684-86.

67. See Shrimp-Turtle, supra note 16, at para. 180; and U.S. Steel, supra note 16. 
Sport from doping decisions. Some international human rights instruments treat access to a court to challenge detrimental decisions as a human right, as, for example, Article 14 of the International Covenant on Civil and Political Rights, and Articles 6 and 13 of the ECHR (although each of these provisions circumscribes its operation in various ways) ${ }^{68}$ In several cases, the European human rights bodies have confirmed the importance of this right in relation to administrative decisions by intergovernmental bodies. Under both Article 6 and Article 13 of the ECHR, state parties must ensure that the procedural standards of the international organizations of which they are members are equivalent to their domestic standards. As for staff employment issues, most international organizations have established review mechanisms, often involving independent tribunals.

How far a right of review is accepted in different governance areas and with what limitations, and what institutional mechanisms it encompasses in such areas, are all unresolved questions. Despite strong calls for effective review mechanisms in several important areas, these have not been instituted. For example, the Security Council has failed to establish an independent body to scrutinize its sanctions decisions. Similarly, the UNHCR has so far accepted only internal mechanisms of supervision. Even in the transitional administration of territories such as Bosnia, Kosovo, or East Timor, international organizations have not been willing to accept a right of individuals to obtain review of intergovernmental agency actions before courts or by other independent bodies with greater powers than ombudspersons.

4. Substantive Standards: Proportionality, Means-Ends Rationality, Avoidance of Unnecessarily Restrictive Means, Legitimate Expectations

Especially when individual rights are placed at the forefront, global administrative law might be expected to embody substantive standards for administrative action, like those applied in a domestic context-such as proportionality, rational relation between means and ends, use of less restrictive means, or legitimate expectations. Proportionality is a central issue in the jurisprudence of some international human rights regimes: in the ECHR, for example, interference with many individual rights can be justified, but only if (inter alia) the interference is proportionate to the legitimate public objective pursued. ${ }^{69}$ The proportionality principle is reflected also in some national court decisions on global governance, such as a German court decision critical of a ruling by an international sports federation in a doping case because it imposed dispropor-

68. International Convention on Civil and Political Rights, Art. 14, 999 U.N.T.S. 171 (1966) [hereinafter ICCPR]; Convention, Arts. 6, 13, opened for signature 4 Nov. 1950, 213 U.N.T.S. 221 (1955).

69. ECHR, Art. 8 (1); see also John Joseph Cremona, The Proportionality Principle in the Jurisprudence of the European Court of Human Rights, in RECHT ZWISCHEN UMBRUCH UND BEWAHRUNG 323 (Ulrich Beyerlin et al. eds., 1995). 
tionate sanctions. ${ }^{70}$ Similarly, restrictions conflicting with the general rules of free trade under the GATT are allowed only if they meet certain requirements designed to ensure a rational fit between means and ends, and employ means that are not more trade-restrictive than reasonably necessary to accomplish the relevant regulatory objective. Yet in many other areas of global administration, the application of such requirements has so far been minimal. ${ }^{71}$

\section{Exceptions: Immunities}

Regarding the immunity of foreign states, national courts have long taken account of the competing interests of private parties, in particular by excluding purely commercial activities from the realm of immunity and thus allowing, for example, for the enforcement of contracts. The law on immunities of international organizations in national courts has not yet integrated such a range of competing values, although there are fragmentary signs of the beginnings of a shift in this direction. In Waite and Kennedy v. Germany, ${ }^{72}$ applicants to the ECtHR complained of a German court decision refusing to reach the merits of the applicants' labor law claim against the European Space Agency (ESA) on the grounds that the ESA, as an inter-governmental organization, enjoyed immunity from suit under German law. ${ }^{73}$ The ECtHR held that the German court decision did not violate Article $6 \S 1$ (right of access to a tribunal) of the ECHR. ${ }^{74}$ However, the ECtHR applied a test of proportionality and weighed in the balance the possibility of internal remedies for the applicants within the ESA, as well as possible remedies against private firms contracting to supply the applicants' labor to the ESA. ${ }^{75}$ This approach of balancing human rights claims against immunity claims creates pressures for such agencies to adopt adequate alternative procedures for vindication of human rights. In a later case, Fogarty v. United Kingdom, ${ }^{76}$ the ECtHR concluded:

Measures taken by a High Contracting Party which reflect generally recognised rules of public international law on State immunity cannot in principle be regarded as imposing a disproportionate restriction on the right of access to court as embodied in article 6(1). Just as the right of access to court is an inherent part of the fair trial guarantee in that article, so some restrictions on access must likewise be regarded as inherent, an example being those limitations generally accepted by the community of nations as part of the doctrine of State immunity.

70. Krabbe v. IAAF et al., Oberlandesgericht Munich, 17 May 1995, cited in GABRIELLE

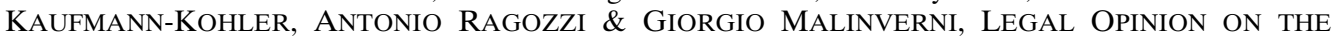
CONFORMITY OF CERTAIN PROVISIONS OF THE DRAFT WORLD ANTI-DOPING CODE WITH COMMONLY ACCEPTED PRINCIPLES OF INTERNATIONAL LAW 32, 121 (2003), available at http://www.wada-ama.org/rtecontent/document/kaufmann-kohler-full.pdf.

71. For a useful overview see EnZo CANNIZZARO, IL PRINCIPIO DELla PROPORZIONALITÀ NELL'ORDINAMENTO INTERNAZIONALE (2000).

72. Waite and Kennedy v. Germany, 30 Eur. H.R. Rep. 261 (1999).

73. Id. at para. 73 .

74. Id.

75. Id. at paras. $59,64,66$, and 70 .

76. Fogarty v. United Kingdom, App. No. $37112 / 97$ 34, Eur. H.R. Rep. 302 (2001).

77. Id. at 314 , para. 36 . 
This recognizes that public international law entails some restrictions on remedial protections for human rights, but the reference to the proportionality concept asserts that traditional immunities may no longer be absolute. ${ }^{78}$

6. Exceptions: Special Regimes for Certain Issue Areas?

In national administrative law, not all mechanisms of accountability apply to the whole range of domestic administrative actors. Exceptions, or at least lower standards, commonly apply, for instance, to matters of national security and to the decisions of central banks. Careful consideration is needed as to the extent to which such exceptions ought to be replicated in global administration. In security matters, the Security Council sanctions regime has established minimal standards for participation, reason-giving, and review, but it has not entirely brushed aside the demands for stronger accountability mechanisms. As for central banks, the European Central Bank has stimulated transnational debate on balances of accountability and independence. In the related area of bank supervision, the Basle Committee has already made significant efforts at broader participation, and national legislatures have begun to press for reports from the national participants in various intergovernmental regulatory regimes before these participants agree to any new recommendations. Reflecting the enormous variations across different global governance arrangements, the current practice is highly variegated. Even in a single organization with multiple areas of competence such as the OECD, different standards of procedural openness prevail in different issue areas, often reflecting the respective cultures in the different issue areas prevalent in national administrations. ${ }^{79}$

\section{IV}

\section{THE NoRMATIVE BASES OF GLOBAL ADMINISTRATIVE LAW}

Participants in either the study or the construction of a global administrative law recognize that these are normative projects, and not simply a taxonomical exercise or the promulgation of practical technical solutions to well-defined and accepted problems posed by global regulatory administration. But the potential normative foundations are as varied as their practical administrative counterparts.

A. Different Patterns of International Ordering and Different Normative Conceptions of Global Administrative Law

Different patterns of international ordering sustain different (sometimes mutually incompatible) normative frameworks for global administrative law, as well as for classical international law and for international institutionalization

78. See Iain Cameron, UN Targeted Sanctions, Legal Safeguards and the European Convention on Human Rights, 72 NORDIC J. OF INT'L L. 159 (2003).

79. See Salzman, supra note 35; see also Dyzenhaus, supra note 41. 
generally. ${ }^{80}$ Some traction on these varying patterns can be obtained by employing the terminology of the English School of international relations, which distinguishes three different patterns of international ordering: pluralism, solidarism, or cosmopolitanism. Inter-state pluralism is the typical pattern of traditional international law, with treaties, international institutions, and international administration limited to areas of agreement between states. As a result, major value conflicts are not resolved and powers of implementation are usually retained by each individual state rather than centralized. Inter-state solidarism envisages deepening powers for international institutions and global administration based on shared values, with cooperation still based on interstate bargaining but with states committed to upholding the global administration system and the various decisions that it produces, even when these conflict with short-term interest calculations. Cosmopolitanism envisages global governance that is not essentially the result of inter-state bargaining, but draws also from cross-border networks of civil society actors, private regulatory and media institutions, and markets. These three patterns are simplified ideal types. ${ }^{81}$ Elements of each of them appear somewhere in the mix of international practice on most issues. But typically, one of these models is understood by the participants as predominating and as shaping the major dynamics of particular issue areas. Thus arms control and disarmament are traditionally highly pluralist fields, the International Criminal Court is a solidarist project, and the governance of global sports issues is primarily cosmopolitan. These conditions of international order are not so much objective descriptions as they are statements of the understandings of the participants, whose approaches and interactions are shaped by what they understand the prevailing dynamic to be.

These different models of international ordering can be juxtaposed to three different normative conceptions of the role of global administrative law: internal administrative accountability, protection of private rights or the rights of states, and promotion of democracy. ${ }^{82}$ The first normative conception for global administrative law, ${ }^{83}$ internal administrative accountability, focuses on securing the accountability of the subordinate or peripheral components of an administrative regime to the legitimating center (whether legislative or executive), especially through ensuring the legality of administrative action. This conception emphasizes organizational and political functions and regime integrity rather than any specific substantive normativity, making it a potential model for an in-

80. See Benedict Kingsbury, Omnilateralism and Partial International Communities: Contributions of the Emerging Global Administrative Law, 104 KOKUSAIHO GAIKO ZASSHI ("THE JOURNAL OF INTERNATIONAL LAW AND DIPLOMACY") 1 (2005).

81. On these ideal types, see Andrew Hurrell, International Law and the Making and Unmaking of Boundaries, in STATEs, NATIONS, AND BordERs: THE ETHICS OF MAKING BOUNDAIRES, 275, 278-87 (Allen Buchanan and Margaret Moore eds., 2003); Benedict Kingsbury, People and Boundaries: An “Internationalized Public Law” Approach, in STATES, NATIONS, AND BORDERS 298, 299-302.

82. On similar normative conceptions behind domestic administrative law, see EBERHARD SCHMIDT-ASSMANN, DAS ALLGEMEINE VERWALTUNGSRECHT ALS ORDNUNGSIDEE (2d ed. 2004).

83. The conception is first chronologically in terms of the evolutionary development of national administrative law and practically in terms of the needs of global administration. 
ternational order, particularly a pluralist one that lacks a strong consensus on substantive norms. The second normative conception is liberal and rightsoriented: administrative law protects the rights of individuals and other civil society actors, mainly through their participation in administrative procedures and through the availability of review to ensure the legality of a decision. It may also be extended to the protection of the rights of states. The third conception views the role of global administrative law as promoting democracy. National administrative law in many countries has a democratic component: it ensures the accountability of administrators to parliament by ensuring their compliance with statutes and to broader economic and social constituencies through public participation in administrative decisionmaking procedures. These three conceptions are sketched here simply to delineate general orientations in the debate. A full treatment of normative issues would require a much more extensive discussion of vastly more complex and nuanced positions, many of which do not fit very closely into these three simple archetypes.

\section{B. Intra-Regime Accountability}

The first conception of global administrative law is the normatively least demanding of the three: it takes a given order for granted and merely seeks to ensure that the various components and agents within that order perform their appointed roles and conform to the internal law of the regime. On this basis, the justification for administrative law is merely functional: it is an instrument to uphold and secure the cohesion and sound functioning of an institutional order that is justified independently.

Any global administrative regime depends for its functioning on the coordinated action of different components and actors, both international or transnational and domestic, and it thus requires mechanisms to ensure that each of them performs assigned roles in accordance with norms of the regime. These mechanisms will usually imply some way of policing the limits of delegation and compliance with rules emanating from the center. The World Bank Inspection Panel can be analyzed in this way as a means for the Board to control management and as a means for central management to control operational managers. The WTO Dispute Settlement Body also operates to some extent as a mechanism to assert and help enforce rules of the global regime against distributed, domestic administrations. Similarly, the emergence of European rules on member-state administrative procedures, allowing for participation in and judicial review of member-state administrative decisions, has enabled European law to be more readily asserted and enforced against recalcitrant domestic regulators. ${ }^{84}$ This element of global administration to some extent mirrors domestic mechanisms such as the oversight exercised by the U.S. Office of Management and Budget (OMB) over federal agencies, but it also reflects an important

84. See, e.g., Johannes MASING, Die MobILISIERUng Des BÜRGERS FÜR DIE DURCHSETZUNG DES RECHTS (1997). 
strand in the development of administrative law in many European countries in the ninteenth century.

In the global order, especially one organized under a pluralist conception, states can be regarded as the center and thus as having a vital interest in policing the limits of any delegation to global administration. Domestic mechanisms, including administrative law mechanisms designed to control transnational or intergovernmental organizations, can perform this policing function insofar as they use the terms of any delegation as the basis for tests of legality. A similar role could be played by international bodies reviewing the action of international organizations. Few such reviewing bodies function on a global level: the major general instance of review remains the episodic jurisprudence of the International Court of Justice on the legality of acts of international organizations, a jurisprudence that continues to leave some issues unresolved, including the Court's capacity to review Security Council action by reference to the U.N. Charter or other rules of international law. ${ }^{85}$ In the European Union, such review is a function of the European Court of Justice (ECJ), though one it performs only reluctantly.

An approach to global administrative law that emphasizes legality and focuses on review as a means of control by the central actors over subordinate or peripheral agencies and actors, is adaptable to different views of international order, and thus may be suited to a wide variety of forms of global administration. It fits into very dense institutional forms of international administration on a cosmopolitan basis, as well as into forms of close cooperation in solidarist orders - that is, among states sharing a strong common set of values. But it has an important function also in pluralist systems, in which common administrative institutions are merely intended to solve collaboration or coordination problems. In all of them, the definitions of center, of subordinate or periphery, and of delegation and supervision, will vary. But they all have to face problems of internal regime accountability and control, and administrative law can contribute useful approaches to such problems.

\section{Protecting Rights}

The second strand of normative goals for global administrative law, the protection of rights, makes stronger normative presuppositions, but is still suited to several different conceptions of international order if the notion of rights is understood broadly. In all administrative law conceptions, the rights in question will ordinarily be those held by the direct subjects of regulation, be these states, individuals, firms, or in some cases NGOs. As in domestic administrative law, the possibility also exists of third-party rights belonging to persons or groups more indirectly affected by regulatory decisions.

85. See generally Jose E. Alvarez, Judging the Security Council, 90 A.J.I.L. 1 (1996); see also B. Martenczuk, The Security Council, the International Court and Judicial Review: What Lessons from Lockerbie?, 10 E.J.I.L. 517 (1999). 
The most common rights-based justification of the need for a global administrative law is based on a conception of individual rights and the associated idea of the rule of law. Administrative infringement of individual rights-whether through the imposition of sanctions, liabilities, disadvantageous determinations of status, denials of required licensing approvals, or otherwise-generally requires a prior hearing for the affected person, specific justifying reasons, and the possibility of review by an independent body. Under such an approach, it is presumed to be irrelevant who interferes with rights: whether it is a domestic regulator or an international administrative body does not matter. ${ }^{86}$ This line of justification seems to underlie several emerging bodies of practice in global administrative law, especially in cases in which global administration directly acts on individuals. Thus, the demand that the Security Council grant some form of due process to individuals listed as sanctions targets reflects the idea of rights protection, as does the insistence of national courts on due process when they comment on the transnational anti-doping regime. National constitutional courts have likewise insisted on the centrality of individual rights protection in their interactions with the ECJ over the protection of fundamental rights in the European Communities.

Advocating global administrative law on grounds of individual rights protection presupposes a priority of liberal values, to be realized perhaps in a cosmopolitan global society that is based on the centrality of the individual. But such a conception is possible also in a non-cosmopolitanist, solidarist international society with a strong emphasis on human rights-and some argue that with the emergence of human rights in universal international law, the international society has reached such a stage today. If global society has indeed reached such a stage, the construction of a global administrative law on such premises would be uncontroversial; only the interpretation of individual rights and rule of law might be contested. ${ }^{87}$ But in a pluralist international society, in which human rights are not protected at all or only minimally protected, the social basis for a global administrative law based on individual rights is largely absent. The problem of individual rights in such an order is particularly pressing because states with a strong liberal foundation will hardly be content with a global administration that does not respect basic rule-of-law principles, yet other states may well object to administrative law measures to protect individual rights, especially as applied to domestic administrations. Once regulation of, and even the provision of, important governmental functions becomes transnational or international, the problem of diverse social orders in different nations and regions becomes central. Since none of the participating states can demand that its own ideas should exclusively govern global institutions, these institutions appear to threaten every state's own way of organizing the state and society. In a pluralist order, this problem is acute because the differences among social orders are

86. See Dyzenhaus, supra note 41.

87. $I d$. 
high; in a solidarist order, its salience will depend on the degree of disagreement over the interpretation of common values.

Similar conflicts and difficulties have already arisen respecting administrative law measures to protect the economic rights and interests of firms and other economic actors in the global market economy; these measures represent a different facet of liberal values. Examples include investor protection measures and arbitral remedies in investment treaties. A successful investor claim under NAFTA of expropriation by Mexican environmental regulations, and a pending arbitral claim by a multinational water service company against Bolivia for the cancellation of its franchise, have sparked wide controversy ${ }^{88}$ The enforcement in WTO member states by multinational firms of intellectual property rights pursuant to TRIPS is creating similar controversies. ${ }^{89}$

Yet a rights-based account of global administrative law can also take a different path: it can base itself on the rights of states. In this approach, tools of administrative law would protect states' rights, and they could serve, for example, to ensure that administrative actors do not overstep their powers vis-à-vis third states, or that they do not exceed their competences vis-à-vis member states. This approach can be based on the need to police the competences of administrative actors. It might be expressed in procedures aimed at enforcing jurisdictional rules: to some extent, mechanisms of classical international dispute settlement perform this function, but so also does dispute settlement in the WTO, insofar as it provides protections against the exercise of over-reaching jurisdiction by national regulators. The Shrimp-Turtle decisions, which grant rights of participation in foreign administrative proceedings to states, might fall into this category. ${ }^{90}$ Other specific mechanisms have also emerged, as for example the attempts by the Financial Action Task Force to consult with nonmember states before taking measures against them. ${ }^{91}$ As to the policing of competences in a vertical rather than a horizontal way, debates about review of the Security Council and of E.U. action indicate possible pathways. From the perspective of rights, such review appears to be less the policing of a delegation of powers than it is the protection of states' rights from encroachment, although both dimensions will often be present.

A states-rights approach to global administrative law could be built on a conception of a pluralist international order, granting rights to states as a means for accommodating diversity and providing limitations on collective action necessary to enlist participation by states. From some states' perspectives, these rights would be based on collectivist theories; for others, they could ultimately be derived from individual rights. Framed this way, a conception of global ad-

88. See Metalclad Corp. v. Mexico, 40 I.L.M. 55, para 33. (NAFTA/ICSID (AF), 2001); see also Aguas del Tunari S.A. v. Republic of Bolivia, Case No. ARB/02/3, pending before the ICSID Tribunal.

89. Graeme B. Dinwoodie and Rochelle Cooper Dreyfuss, International Intellectual Property Law and the Public Domain of Science, 7 J. INT'L ECON. L. 431 (2004).

90. See Cassese, supra note 13.

91. See Financial Action Task Force website, supra note 52. 
ministrative law based on states' rights might be rather limited, but well suited to a pluralist order. Even in cosmopolitan or solidarist orders with strong common values and a commitment to human rights, states' rights might be useful in organizing the representation of individuals or of social and economic group interests on the global level. They are then comparable to rights of local entities or states in a federal system as expressions of both administrative utility and of cultural diversity within the greater entity. In a solidarist or cosmopolitan society, such a framing can easily coexist with a justification on the basis of individual rights, as it usually does in federal systems or in the European Union.

\section{Implementing Democracy}

The third strand, normatively the most demanding, would reference democratic ideals in assessing the need, performance, and possibilities of global administrative law. This conception of the normative function of global administrative law can be interpreted in a variety of ways.

Some proponents emphasize the ways in which domestic administrative law serves democracy by ensuring administrative adherence to parliamentary statutes and providing transparency and the participation of the public in administrative rulemaking. These ways may vary depending on the legal systems involved: for example, among public participation requirements, U.S. administrative law emphasizes judicially enforced obligations of agencies to adequately consider the various social and economic interests affected by their decisions, and to provide a reasoned justification for the policy choices that they make. Such justification has to include responses to the views and comments submitted by representatives of those interests through the public participation mechanisms. This judicialized conception of public participation, however, finds only limited expression in many other national systems. ${ }^{92}$ National democratic systems vary in their means of operationalizing democratic control, and thus diverge in their ways of managing the discretion that effective administration requires. Some use parliamentary controls or executive controls, such as centralized control systems that employ cost-benefit analysis; others rely on experts, administrative law procedures, and judicial review. Despite these differences, however, administrative law in all these jurisdictions is centrally concerned with ensuring democracy.

Some would have global administrative law serve these same functions for administrations that operate transnationally or internationally. This idea of a democratic role for global administrative law is easily stated, but it faces a number of serious problems of definition and implementation. First, there are doubts that international society today sufficiently agrees on democratic stan-

92. On different conceptions and traditions of participation rights and their development in the European Union, see Francesca Bignami, Three Generations of Participation Rights before the European Commission, 68 L. \& CONTEMP. PROBS. 61 (Winter 2004). On the different approaches to participation in administrative rulemaking, see THEODORA TH. ZIAMOU, RULEMAKING, PARTICIPATION AND THE LIMITS OF PUBLIC LAW IN THE USA AND EUROPE (2001). 
dards to use them as the foundation for a common, global administration. Second, the domestic model of administrative law is founded on a particular institutional structure, based on a central democratic lawmaking body and the laws that it enacts. A similar system of representative global democracy is today advocated by some, ${ }^{93}$ but usually regarded as illusionary or even dangerous. Independent reviewing courts, which are central to domestic administrative law, are also lacking at the global level. Thus, a global administrative law would have to be built on very different grounds: it would either have to democratize international lawmaking so that ensuring the legality of administrative action would promote democratic accountability; or it would have to construct administrative procedures that can shoulder the democratic burden alone. ${ }^{94}$ So far, however, both options face the fundamental problem that convincing democratic theories for the global sphere are still lacking. If electoral or other models of direct representation fail, most of what is left is recommendations for different forms of participatory or deliberative democracy, ${ }^{95}$ and these have hardly resolved the problems of defining "the public" that is supposed to govern or be represented globally, ${ }^{96}$ or of designing the mechanisms by which global participation or deliberation can indeed occur. ${ }^{97}$ Forms of democratic experimentalism, perhaps suited to the European Union, ${ }^{98}$ usually need to be embedded, at least to some extent, in an otherwise stable and well-developed environment of democratic institutions. While deliberation in regulatory institutions might provide good results, ${ }^{99}$ without more it is unlikely to provide the coupling with the public that will be necessary to give it democratic credentials. ${ }^{100}$ Such forms of deliberative technocracy might suffice if global regulatory administration did not involve major distributional choices and conflicts. ${ }^{101}$ But as global regulatory administration intensifies, important distributional issues are becoming more evident and more widely contested in many fields. Not surprisingly, then, the question

93. See Richard Falk \& Andrew Strauss, Toward Global Parliament, 80 ForeIGN AFF. 212 (2001).

94. For a similar problem in the E.U. context, see Renaud Dehousse, Beyond Representative Democracy: Constitutionalism in a Polycentric Polity, in EUROPEAn CONSTITUTIONALISM BEYOND THE STATE 135 (Joseph H.H. Weiler \& Marlene Wind eds., 2003).

95. See Robert L. Howse, Transatlantic Regulatory Co-operation and the Problem of Democracy, in TRANSATLANTIC REGULATORY CO-OPERATION 469, 478-80 (George A. Bermann et al. eds., 2000).

96. See the critique in Ruth Grant \& Robert Keohane, Accountability and Abuses of Power in World Politics, IILJ Working Paper 2004/7, 14, at http://iilj.org/papers/2004/2004.7\%20Grant\%20 Keohane.pdf.

97. See, e.g., Jürgen Habermas, The Postnational Constellation (Max Pensky trans. \& ed., 2001).

98. See Charles Sabel \& Jonathan Zeitlin, Networked Governance and Pragmatic Constitutionalism: The New Transformation of Europe (unpublished manuscript, on file with the authors).

99. See Joerges, supra note 24.

100. See the relevant critique in Martin Shapiro, "Deliberative," "Independent" Technocracy v. Democratic Politics: Will the Global Echo the E.U.?, 68 L. \& CONTEMP. PROBS. 341 (Summer/Autumn 2005).

101. On the lack of salience of many areas of E.U. regulation in this context, see Andrew Moravcsik, supra note 25, at 25-26; see also FRITZ SCHARPF, GOVERNING EUROPE: EFFECTIVE AND DEMOCRATIC? (1999). 
of a democratic theory for global administration is in urgent need of a convincing answer, but is most unlikely to get one anytime soon.

Yet a democracy-enhancing conception of global administrative law might not depend on a full-fledged democratic theory for the global level. In this regard, Anne-Marie Slaughter has suggested that many problems of democratic accountability could be solved if global administration were to operate mainly in the form of government networks, in which the participating national officials could be made democratically accountable to their respective publics through domestic institutions. ${ }^{102}$ She reasons that securing such accountability to domestic publics is likely to be easier in the case of networks than formal, treaty-based international organizations, which have far greater effective autonomy. Pursuit of such accountability entails strengthening domestic mechanisms, including extension and development of domestic administrative law mechanisms to govern the participation of national officials in global administrative decisionmaking. This strategy might indeed enhance a certain brand of democratic legitimacy, but its effectiveness in doing so will probably be limited in important ways by the practical dynamics of decisionmaking in intergovernmental networks. Further, given that global administration operates through a number of other important types of institutions in addition to intergovernmental networks, this strategy would provide only a partial solution. Finally, and most fundamental, while such a strategy is well-suited to a pluralist pattern of international ordering because it ties accountability for global decisionmaking back to the separate legal and political institutions of each participating state, for the same reasons it may actually work against the realization of solidarist or cosmopolitan conceptions of international administration.

Perhaps, then, it would be advisable for global administrative law to pursue a less ambitious and more pragmatic approach. It could, for example, recognize that under current circumstances, no satisfactory democratic basis for global administration is available but that global administrative structures are nevertheless required to deal with problems national democracies are unable to solve on their own. In this non-ideal situation, global administrative law might take pragmatic steps towards a stronger inclusion of affected social and economic interests through mechanisms of participation and review open to NGOs, business firms, and other civil society actors, as well as states and international organizations. Yet, such steps fall short of representation of the public on a basis equivalent to domestic electoral mechanisms and thus will not be able to justify the exercise of administrative authority on a fully democratic basis. And for each step, the construction of a global administrative law with democratic goals would have to reassess the costs and benefits of broad-based participation, thus integrating practical experience in the gradual development of public accountability.

102. See SLAUGHTER, supra note 34. 
Under a still more limited approach, global administrative law could set aside the goal of democratizing global administration and focus on the other justificatory roles discussed previously, controlling the periphery to ensure the integral function of a regime, protecting rights, and building meaningful and effective mechanisms of accountability to control abuses of power and secure rule-of-law values. Accordingly, the better interim course might be to bracket questions of democracy (while nurturing democratic attributes and tendencies where viable), and to focus on attaining more limited but nonetheless important objectives. $^{103}$ Whether this is feasible or indeed desirable, though, is a central, open question in the further development of global administrative law.

\section{E. Who is Shaping Global Administrative Law?}

Many of the emerging mechanisms of global administrative law stem from northern and western initiatives, and any attempt at justifying the need for such a body of law must thus face the challenge of intellectual and political bias. This challenge can come in two forms, one of which concerns the underlying normative ideals.

The models of administrative law used in this essay and throughout the project are of European and American origin, and are closely connected with the rise of the liberal state and the expansion of its regulatory and administrative activities in the late nineteenth and early twentieth centuries. ${ }^{104}$ Thus, transferring these models to the global administrative space may seem to imply a liberal order for that sphere, at the expense of somewhat different ways of ordering society that exist especially in Asia and Africa. But not all normative bases of global administrative law are connected to a liberal model of society. Approaches focused on intra-regime control and protecting states' rights might just as well apply in a non-liberal order. However, in order to justify a more demanding conception of global administrative law (and one more congenial to democratic views), it is unlikely that reliance solely on these two approaches will suffice; instead, justifications must probably be based, in one way or the other, on individual civil rights, economic rights, and democracy, reflecting in some measure solidarist or cosmopolitan conceptions of international ordering. Yet even a limited form of such reconceptualization could face political challenges: an international order based on individual or economic rights may be too close to Western, liberal conceptions to be universally acceptable. Emphasizing the organizing role of state sovereignty may prove superior in coping with the challenge of diversity. ${ }^{105}$

A principal challenge will thus consist in learning about and determining the extent to which common conceptions of individual or economic rights and de-

103. See Grant \& Keohane, supra note 96.

104. We treat European and American administrative law traditions and their derivatives here as part of one family, which is, however, not meant to downplay the important differences between various traditions.

105. See Benedict Kingsbury, Sovereignty and Inequality, 9 E.J.I.L. 599 (1998). 
mocracy can serve as a basis for global administrative law; it may be that more demanding conceptions of supra-national administrative law will have to be limited to administrative bodies operating in regions or sectors that share a sufficient depth of common values. ${ }^{106}$ On the other hand, it will be necessary to inquire into alternative conceptions of administrative law in other models of society, which may be operationalized in institutions similar to those of Western administrative law, even if they have a different normative basis. In this case, global administrative law might be built not so much on a coherent normative system, but rather on some kind of "overlapping consensus." The extent to which this might be possible is a question requiring further research and vigorous debate.

A second challenge might focus on the current international institutional order that global administrative law seeks to build on and improve. In a radical form of critique, the current institutions of global governance can be seen as "imperial" institutions, furthering the goals and stabilizing the dominance of Northern industrialized countries at the expense of the South, and of the dominant capitalist classes at the expense of subaltern peoples. ${ }^{107}$ Suppose this charge were correct (and it is certainly plausible): what would this mean for global administrative law? Defenders would probably argue that global administrative law seeks to improve current institutions and, by making them more accountable, might lay the seeds for a future empowerment of those currently underrepresented and excluded. Critics, however, might claim that the strategy of global administrative law is far too limited; that even if it succeeds, it would only scratch the surface of the current institutional injustice. Moreover, it would at the same time help legitimate the current order and thus stabilize it, whereas radical change is actually needed. This would recall the classical and intractable debates between reformers and revolutionists, in which both sides are probably right in some way. But it would also point to the need for thinking about distributional issues and ways to achieve greater accountability of global administration to those who are the most excluded today. Most initiatives currently proposed would have the effect of increasing accountability towards Northern populations, market actors, social interests, and states. Increasing the ability of such actors to hold global governance to account may aggravate the cleavages currently existing in the world, and might weaken institutions that offer the most promise to disadvantaged groups. In order to address the central problems of accountability, global administrative law might have to devise ways to empower and include people and their representatives from the South. From this perspective, a more effective participation of the developing world in global administrative structures might be more urgent than implementing yet another path of influence for the affluent parts of the world.

106. For such a proposal see JÜRGEN HABERMAS, DER GESPALTENE WESTEN (2004).

107. See Bhupinder Singh Chimni, International Institutions Today: An Imperial Global State in the Making, 15 E.J.I.L. 1 (2004). 


\section{V \\ STRATEGIES AND THEORIES OF INSTITUTIONAL DESIGN}

The construction of a global administrative law is inevitably shaped and constrained by existing institutions and principles as well as the shifting patterns of international ordering and the normative foundations outlined in the preceding parts of this article. Within these constraints, many strategies of institutional design are possible.

A. Strategies and Pathways for the Development of Global Administrative Law

Two general approaches to constructing global administrative law are evident in current practice. One focuses on the application of domestic administrative law to global administration "bottom-up," the other on constructing international mechanisms "top-down." ${ }^{108}$ A threshold question is whether and to what extent any approach to the development of global administrative law can sensibly begin with approaches developed for the legal control of administration in domestic contexts.

1. Constraints on Transposing Tools from Domestic Administrative Law

The transposition of tools and approaches from domestic administrative law to global governance issues may be productive, but it faces important limits, stemming mostly from the different structure of global administration-from the relative informality of many of its institutions, its multi-level character, and the strength of private actors in it.

a. The informality of global administration. Domestic administrative law is, despite many changes in regulatory techniques in recent decades ${ }^{109}$ still built around a core of command-and-control administration-of rules and decisions binding on private actors, emanating from a defined administrative entity. In global administration, no such core typically exists: with some exceptions, global administration consists mostly of administrative bodies with the power to make recommendations but not binding rules, or of regulatory networks or other intergovernmental cooperative arrangements with informal decisionmaking procedures. At the domestic level, the challenges posed to administrative law by similar arrangements can perhaps remain unsolved without too much harm so long as most important regulatory programs are carried out through

108. See Stewart, supra note 5. For an example of a parallel debate, see Reuven Avi-Yonah's proposal for a World Investment Organization to regulate multinational enterprises and Merritt Fox's skeptical response, Reuven Avi-Yonah, National Regulation of Multinational Enterprises: An Essay on Comity, Extraterritoriality, and Harmonization, 42 Colum. J. TRANSNAT'L L. 5 (2003); Merritt Fox, What's So Special About Multinational Enterprises?: A Comment on Avi-Yonah, 42 COLUM. J. TRANSNAT'L L. 551 (2004).

109. See generally Richard B. Stewart, Administrative Law in the Twenty-First Century, 78 N.Y.U.L. REV. 437 (2003). 
traditional, legally binding instruments. However, this condition does not hold true globally. It is often unclear in which global decisionmaking arrangements one could or should establish participatory rights, or which actions should be reviewable when binding instruments and decisions are absent. These problems cannot be avoided by instituting binding, command-and-control administration on a widespread basis at the global level, since this would imply a more farreaching delegation of powers to global institutions than is realistic for the near future. In distributed administration, these challenges are less severe because global administrative law requirements can be imposed on existing domestic regulatory administrations.

b. The diffusion of decisionmaking in a multi-level system. A clear attribution of responsibility for decisions is central to domestic administrative law, as it allows distinct government entities to be held accountable. Yet on the global level, because of the often cooperative structures of multi-level governance, such targeted responsibility is usually difficult to establish. Instead, decisions will often be attributable to domestic, foreign, and international actors together. For good reason-often these actors must act in common. In some respects, this problem mirrors similar difficulties in the European Union, which may also remain unresolved. ${ }^{110}$

c. The private element in global administration. Domestically, private actors often assume regulatory functions, but many of them under structures of delegation from public bodies, and all embedded in an order in which public bodies, both administrative and legislative, possess relatively effective means of intervention to control or correct private governance. On the global level, such a public order is largely lacking, yet private bodies perform far-reaching tasks, often spurred by the absence of effective public regulation. In these circumstances, it is unclear how accountability for private governance can be organized. Some global private governance organizations, such as ISO and international sports federations, have adopted certain procedures of accountability and review in order to enhance their effectiveness and legitimacy; these may have parallels in domestic administrative and private law that are so far underexplored. ${ }^{111}$

All these issues pose problems for the transposition of domestic administrative law. They point to the need for drawing more on insights from the fringes of domestic administrative law and research into its anomalous forms, if domestic tools are to become useful for the global level. Perhaps most suggestive for administrative lawyers, however, is the prospect that the laboratories of innovation in global administrative law may generate new ideas for domestic adminis-

110. See, e.g., Eberhard Schmidt-Aßmann, Verwaltungskooperation und Verwaltungskooperationsrecht, in der Europäischen Gemeinschaft, 31 EUROPARECHT 270 (1996); see also Cassese, supra note 13; della Cananea, supra note 13; Chiti, supra note 13.

111. Joerges is one of the initiators of contemporary exploration of this area. See supra note 24. 
trative law, as many of the core problems of global administrative law are increasingly being recognized in domestic law too.

Within the limits set by these constraints, two basic orientations to the development of global administrative law can be distinguished in existing practice: a bottom-up approach, and a top-down approach.

\section{The Bottom-Up Approach}

The bottom-up approach attempts to ensure legality, accountability, and participation in global administration through extending (and adapting) the tools of domestic administrative law. Pressures for such extension arise when it appears that transnational or global governance institutions are taking over formerly national administrative functions that were previously subject to domestic administrative law mechanisms of transparency, participation, and review, but are not so constrained at the global level. Such pressures intensify when it appears that national regulators participating in this extranational governance are using it to shelter their actions from effective review at the domestic level. In order to remedy this circumvention of domestic administrative law safeguards, the bottom-up approach would apply requirements of transparency, notice-andcomment procedures, and review-not only to the international components of domestic administrative decisions, but also to the participation of domestic administrators in global regulatory decisionmaking-and it would require decision-making transparency in order to support such participation. It would allow for scrutiny of the international regulatory process in judicial review of domestic administrative action that aims at implementing international decisions, and possibly also scrutiny of the positions developed by domestic officials before and even during their participation in global-level decisionmaking. It would also extend the review powers of domestic courts to include international decisions directly affecting individuals, with the possibility of setting them aside if they infringe upon individual rights or show procedural flaws. ${ }^{112}$ Different standards of procedure and review than those applying to the domestic level would be conceivable here. Thus, less demanding procedural requirements and a greater level of deference by reviewing bodies might be applied to decisions taken by national officials in the context of global decisionmaking than to analogous purely domestic administrative decisions because of the imperatives of confidentiality, flexibility, and speed in international negotiations. Alternatively, more rigorous requirements and less deference might be applied, on the premises that global administrative policymaking is inherently more opaque and less susceptible to informal mechanisms of participation and review than

112. On attempts of European courts to review "preparatory" acts in the multi-level context of the E.U. see Cassese, supra note 13; see also della Cananea, supra note 13. But on related problems, see Mario P. Chiti, Forms of European Administrative Action, 68 L. \& CONTEMP. PROBS. 37-57 (Winter 2004). For an assertion of the right to set aside supranational decisions, see Bundesverfassungsgericht (Federal Constitutional Court) [hereinafter BVerfG], Judgment of October 12, 1993 (Maastricht), 89 Entscheidungen des Bundesverfassungsgerichts [hereinafter BVerfGE] 155 (English translation in 33 I.L.M. 395 (1994)). 
comparable domestic policymaking, and that it is not embedded in a parliamentary framework that would exercise control. ${ }^{113}$

Since, in many of its parts, global administration is made up of domestic regulators cooperating, and since it often depends for its effectiveness on domestic implementation, such a bottom-up approach might actually be effective in ensuring accountability, and it might be a powerful tool to link global administration to democratic procedures. However, it also faces important limitations and problems. As noted above, this approach could be implemented rather easily in the case of global decisionmaking by intergovernmental networks, but it will be much more difficult to apply to formal international organizations or to hybrid or private governance arrangements. It is difficult to see how it could be applied at all to distributed administration by other states. Further, implementing this approach would require some way to order the diversity of techniques that are bound to develop when different countries establish their own procedures and thus seek to influence global administrative bodies in diverging ways. Implementation of the bottom-up approach would also be confronted by serious objections that powerful states have far greater influence on global administration than do weaker states. And those seeking to implement the approach will have to deal with the question of the relevant constituency: to which public or publics should global administration be accountable? If the relevant public is global or trans-border in character and different from the sum of the national publics, domestic procedures may be insufficient, at least in their traditional form. This might also be true for the application of domestic administrative law to distributed global administration: here, too, it might be necessary to devise ways to include a broader set of interests than just the national public.

The bottom-up approach is fundamentally constrained because, while domestic administrative law systems provide valuable ideas, they are not generally applicable as direct models for understanding and problem-solving in the quite different conditions presented by the global administrative space. Most domestic systems of administrative law address the issue of executive branch officers or administrative agencies (whether or not politically independent) exercising authority delegated to them by a parliamentary statute. In exercising this authority, agencies are required to follow particular procedures involving the participation of affected parties or a broader public. If a person with standing decides to contest a decision, the case is subject to review by independent, mostly judicial bodies by reference to procedural and substantive legality. ${ }^{114}$ This model does not fit easily with the structures of international law and global governance, for reasons mentioned above: the lack of a democratic anchor through a central plenary law-making authority or a delegation of powers from national democratic organs; the wide-spread absence of specific participatory and review mechanisms and the mostly non-binding character of global regulation; and the

113. For greater detail see Stewart, supra note 5.

114. $I d$. 
state-centered structure of international law that renders individual participation and standing difficult. Therefore, global administrative law, while drawing some concepts from domestic administrative law, must start from different structural premises in order to build genuinely global mechanisms of accountability. This may imply a different normative starting point-one that would perhaps not rely so much on justification through individual rights and democracy, but, in a pluralist conception, on firmer accountability of global administrators to international regimes and participating states or, in solidarist or cosmopolitan conceptions, on ensuring accountability to the emerging international community as such. And it may involve different institutional mechanisms-mechanisms that are in some cases perhaps entirely detached from democratic foundations and represent more pragmatic means of checking the power of administrative actors. ${ }^{115}$

\section{The Top-Down Approach}

The second strategy for constructing global administrative law, the top-down approach, would more closely resemble contemporary international law patterns, and would thus avoid some of the problems involved in applying domestic mechanisms of administrative law to global institutions and actors. It would build accountability mechanisms at the global level: individuals, groups, and states would participate in global administrative procedures; review of decisions would be performed by independent international bodies, and this would include the review of domestic decisions forming part of distributed global administration. But this would also pose new difficulties: it would require legalization and institutionalization of administrative regimes that are at present informal, which is difficult to achieve without losing the benefits of informal modes of cooperation; and powerful states and economic actors will generally be suspicious of strongly legalized regimes because they reduce their discretionary influence. Moreover, a top-down approach might produce far greater democratic problems than one based, at least in part, on accountability in domestic fora. Also, a top-down strategy for constructing global administrative law must confront many of the same difficult challenges as a bottom-up approach, including the diffusion of decisionmaking in a multi-level system, the often indirect effects of global administrative decisions, the difficulty of providing nonstate actors with rights of participation and review within the state-centered orientation of many global administrative regimes, and the significant private element in global administration.

Both the bottom-up and top-down approaches to constructing global administrative law present significant problems. It is therefore necessary to consider other possible models. 
B. Beyond the Domestic Analogy? Alternative Accountability Mechanisms

Ruth Grant and Robert Keohane point to the general dearth in global governance of checks and balances, to the non-delegated nature of the power of most important actors, and to the lack of a defined global public. ${ }^{116}$ This analysis also raises the question of whether alternative accountability mechanisms can be crafted. Such mechanisms would go beyond the usual mechanisms of domestic administrative law: they would include forms of hierarchical, supervisory, and legal accountability, backed by pressures from markets and from peers, by financial controls, and by public reputational dynamics. ${ }^{117}$ An added advantage of such a shift would be a broadened range of actors covered: while administrative law concepts usually focus mainly on public actors and especially on those to whom power has been delegated, these mechanisms could also be applied to private actors, such as NGOs or firms, and to states, the main power-wielders in international affairs.

The approach proposed by Grant and Keohane is attractive, in particular since it points to (and seeks to overcome) serious limitations of an administrative law conception of global accountability mechanisms based on domestic models. Yet Grant and Keohane acknowledge that any system based on accountability has serious limitations; in particular, powerful states will usually be checked by negotiation constraints rather than by accountability mechanisms. There is also some value in continuing to work within the particular limitations of the administrative law approach. It builds upon insights from the domestic realm and exposes the structural obstacles to applying them globally; all theorizing needs to work against some background, and the background of administrative law is particularly rich despite receiving little attention so far from theorists of international affairs. Moreover, the proposed alternative mechanisms can be understood as variants on the tools of administrative law: after all, hierarchical, supervisory, and legal accountability are well-known to administrative lawyers. The other mechanisms may be viewed as complements that may compensate for some of the shortcomings of administrative law tools. The object of work in this line would be to develop a suite of accountability mechanisms for global administration in which administrative law would play an important part; structural linkages between administrative law and other mechanisms would have to be carefully considered.

Another possible model is the dynamic experimentalist vision of benchmarking, borrowing, innovating, monitoring, and mutual learning, exemplified to some extent in the European Union's Open Method of Coordination. ${ }^{118}$ In this vision, different institutions and actors on the same or different levels would not stand in clear hierarchical relationships or exercise review of one another, but would rather operate alongside each other, seeking to obtain maxi-

116. Id. at 14 .

117. Id. at 18 .

118. See Sabel \& Zeitlin, supra note 98. 
mum information and ideas and cooperating, as well as competing, in the quest for (provisionally) best solutions. This would not have to be confined to public bodies, but could also include a wealth of private bodies engaged in global administration. Another alternative model is one of mutual challenge and reinforcement: different levels of participation and review would remain in an unclear relationship, allowing each to challenge the others on the basis of their own normative principles and standards. Examples would include national court challenges to international institutions such as the U.N. Security Council; or challenges to domestic administrative procedures by the WTO Appellate Body. ${ }^{119}$ This could, over time, lead to a strengthening and mutual adaptation of accountability mechanisms in the different layers of global administration. In this sense, it might be seen as a provisional approach; but it might also be a more permanent feature of a global administrative space, in which notions of legitimacy and justice are likely to remain contested and divergent for a long while.

The advantages and disadvantages of such approaches have not yet been fully explored. Nor has the potential more generally of other non-traditional tools of domestic administrative law as sources of ideas for global regimes. ${ }^{120}$ For example, public-private networks and economic incentive mechanisms have become prominent in domestic administration, and they may be preferable to the classical command and control tools of administrative law in a global setting characterized by a lack of traditional enforcement capacities. Yet challenges confronting these innovations within domestic systems, particularly challenges in establishing accountability to a broader public through prevailing mechanisms of administrative law, are likely to be acute if they are transposed to global administration. Some other proven domestic tools for promoting official accountability, such as requiring agencies to base regulatory decisions on costbenefit analysis, subject to administrative review by a separate body connected with the elected government leaders, or tort law, may be less exposed to these challenges if used in global administration, but would face severe problems of effectiveness.

\section{VI}

\section{The Positive Political Theory of Global AdMinistrative LAW}

The positive political theory of global administrative law, though central to understanding the emerging mechanisms and to building and applying effective institutional strategies, is so far quite underdeveloped. Identifying institutional and developmental regularities is especially difficult in this field, given the fragmented nature of international institutions and the wide variety of actors

119. For a parallel interpretation of developments in the E.U., see Miguel Maduro, Europe and the Constitution: What if This is as Good as it Gets?, in EUROPEAN CONSTITUTIONALISM BEYOND THE STATE 74.

120. See Stewart, supra note 5. 
pursuing their interests through them. It will accordingly be difficult to come up with any conclusions as general as those scholars have advanced on the domestic level. ${ }^{121}$

Highlighting the need to stay attuned to the specificities of each regime, Eyal Benvenisti has suggested four different factors as central to the development of global administrative law: inter-state competition, domestic competition, internal competition within the respective institution, and competing values among the different actors. ${ }^{122}$ Given that these factors will interact very differently in different settings, it will be difficult to draw from these factors any concrete regularities or even predictions of institutional development. Yet Benvenisti cautiously advances several hypotheses that will merit further testing. Among them is the reluctance of powerful states to agree to mechanisms of global administrative law, unless they see those mechanisms as furthering their own views and interests. ${ }^{123}$ Another is a tendency of democratic states with a strong domestic opposition to push for stronger accountability mechanisms in international institutions. ${ }^{124} \mathrm{~A}$ third is an inclination of review bodies to create strong administrative rules when the actors within the institution show a large extent of disagreement, thus opening space for independent action. ${ }^{125}$

Benvenisti also hypothesizes that strong accountability mechanisms will often evolve in situations of delegation of powers. ${ }^{126}$ This fits nicely with the observation by Grant and Keohane that it is in delegation structures that accountability mechanisms can work best; the relationships between delegation and accountability certainly need more detailed analysis. ${ }^{127}$ Yet global administrative law is also emerging outside of structures of delegation, often driven by a desire for legitimacy (or public reputation) on the part of the administrative bodies themselves. In the OECD, for example, it was out of a moment of crisis and contestation (around the Multilateral Agreement on Investment) that efforts at greater transparency and inclusion emerged. This would correspond well with Benvenisti's hypothesis that administrative law mechanisms are a function of the power relations among different actors, but with the annotation that it is especially through moments of legitimation crises that new actors, like NGOs, gain power and momentum in demanding inclusion through new procedures. ${ }^{128}$ In areas with a strong public presence of NGOs, especially in environmental matters, mechanisms of participation are often particularly developed.

121. For the domestic level, see Matthew D. McCubbins, Roger Noll, \& Barry R. Weingast, Politics and the Courts: A Positive Theory of Judicial Doctrine and the Rule of Law, 68 S. CAL. L. REV. 1631 (1995); see also Matthew D. McCubbins, Roger Noll, \& Barry R. Weingast, The Political Origins of the Administrative Procedure Act, 15 J.L. ECON. \& ORG. 180 (1999).

122. See Eyal Benvenisti, Public Choice and Global Administrative Law: Who's Afraid of Executive Discretion?, 68 L. \& CONTEMP. PROBS. 319 (Summer/Autumn 2005).

123. Id. at 329-30.

124. Id. at 331-33.

125. Id. at 333-34.

126. Id. at 334-35.

127. See Grant and Keohane, supra note 96, at 8-9.

128. Benvenisti, supra note 122, at 329-30. 
In situations that are, like these, not characterized by delegation structures, another argument of Grant and Keohane becomes relevant: namely that for accountability to be realized, the standards of accountability must be spelled out as precisely as possible. ${ }^{129}$ This would point to an important role of substantive law: by defining the powers and limits of global administrative actors, review bodies would be able to exercise more effective control and participatory procedures would take on more importance.

\section{VII \\ CONCLUSION}

This article has sought to provide a survey of major developments and central questions in the emerging global administrative law. Since this field is still in its infancy, all the issues we have outlined require much more research and debate-neither the structural and empirical questions, nor the doctrinal or normative issues, nor the questions concerning institutional design and positive political theory have yet received satisfactory answers. More fundamentally, there remains scope for real contestation about whether it is useful either to speak of "global administration" and "global administrative space" or to advocate "global administrative law" as a field of study.

To address these questions, collaborators in the NYU Research Project on Global Administrative Law and comparable initiatives are analyzing a wide variety of cases in which administrative law, or mechanisms, rules, and procedures comparable to administrative law, are used to promote transparency, participation, and accountability in informal, cooperative, and hybrid structures and in multi-level systems with shared responsibility in decisionmaking. Defining a field of global administrative law may help draw connections among specialist areas of theory and practice, and thus reveal parallels and contradictions that were not noticed earlier. With a wide set of case studies of practice in particular areas, coupled with efforts to develop comparative and synthetic conceptual structures and normative theories, questions about the design of and need for mechanisms of transparency, participation, review, and legality in global administration may be more fully addressed. Moreover, a deeper analysis of doctrinal features and divergences will be possible, and hypotheses of positive political theory can be developed and tested.

Work on the normative issues is likely both to deepen transnational and global democratic theory and to raise challenging questions about its application to specific administrative structures and to the whole project of global administrative law. Normative inquiries will also enrich operational understandings of the place of diversity, equality, and equity in global administrative law. The need for alternative approaches to the currently dominant models of global governance and administrative law is pressing but is just beginning to be addressed.

129. Id. at 334-35. 